September 27, 2003

\title{
Does Investor Misvaluation Drive the Takeover Market?
}

\author{
Ming Dong ${ }^{a}$
}

\section{David Hirshleifer ${ }^{b}$}

\section{Scott Richardson ${ }^{c}$}

\section{Siew Hong Teoh ${ }^{d}$}

This paper tests the hypothesis that irrational market misvaluation affects firms' takeover behavior. We employ two contemporaneous proxies for market misvaluation, pre-takeover book/price ratios and pre-takeover ratios of residual income model value to price. Misvaluation of bidders and targets influences the means of payment chosen, the mode of acquisition, the premia paid, target hostility to the offer, the likelihood of offer success, and bidder and target announcement period stock returns. The evidence is broadly supportive of the misvaluation hypothesis.

${ }^{a}$ Schulich School of Business, York University, 4700 Keele Street, Toronto, Ontario M3J 1P3, Canada; mdong@schulich.yorku.ca

${ }^{b}$ Fisher College of Business, The Ohio State University, Columbus, OH 43210-1144; hirshleifer_2@cob.osu.edu, http://www.cob.ohio-state.edu/fin/faculty/hirshleifer/

${ }^{c}$ Wharton School, University of Pennsylvania, Philadelphia, PA 19104-6365,

scottric@wharton.upenn.edu,http://accounting.wharton.upenn.edu/faculty/richardson/ ${ }^{d}$ Fisher College of Business, The Ohio State University, Columbus, OH 43210-1144; teoh_2@cob.osu.edu

We than the editor, Rick Green; an anonymous referee; Francois Derrien, Peter Easton, Mark Grinblatt, Jack Hirshleifer, Shawn Humphrey, Danling Jiang, Steve Kaplan, Andrew Karolyi, Sonya Seongyeon Lim, John Lott, Gordon Phillips, Jay Ritter, David Robinson, Anna Scherbina, Andrei Shleifer, Christof Stahel, René Stulz, Tuomo Vuolteenaho, Ralph Walkling, Karen Wruck, Jeffrey Wurgler; participants at the 2003 Western Finance Association Meetings in Los Cabos, Mexico, the 2003 European Finance Association Meetings in Glasgow, Scotland, the 2003 National Bureau of Economic Research Behavioral Finance Program Meeting at the University of Chicago; the 2003 conference "Analyzing Conflict: Insights from the Natural and Social Sciences" at UCLA, and at seminars at Columbia University, Harvard Business School, Ohio State University, Tilburg University and York University for very helpful comments and suggestions. 


\section{Does Investor Misvaluation Drive the Takeover Market?}

This paper tests the hypothesis that irrational market misvaluation affects firms' takeover behavior. We employ two contemporaneous proxies for market misvaluation, pre-takeover book/price ratios and pre-takeover ratios of residual income model value to price. Misvaluation of bidders and targets influences the means of payment chosen, the mode of acquisition, the premia paid, target hostility to the offer, the likelihood of offer success, and bidder and target announcement period stock returns. The evidence is broadly supportive of the misvaluation hypothesis. 
The biggest reason AOL Time Warner has been such a dog for investors is that the deal creating the company was done on terms that were insane. And the really painful part is that this was perfectly clear at the time. .... Trouble was, AOL stock was ridiculously overvalued... So don't blame Case for what has happened. He chose the moment, almost to the day, when his stock was most valuable and then used it as currency. He served his shareholders well. It was Time Warner that sold itself for wampum.

—Geoffrey Colvin, "Time Warner, Don’t Blame Steve Case," February 3, 2003, Fortune.

\section{Introduction}

Despite a rising interest in psychological approaches to economic decisions in recent years, there has been relatively little study of the degree to which market misvaluation of firms influences investment decisions. ${ }^{1}$ An important kind of investment is the purchase of another firm, and a great deal of data are available about the terms and characteristics of takeover transactions. The takeover market is therefore an attractive testing ground for the hypothesis that market misvaluation affects resource allocation and the strategic interaction of firms.

The idea that inefficient market misvaluation is an important driver of the takeover market is not new. For example, Brealey and Myers (2000) (p. 949) discuss a 'bootstrap' game, allegedly important during the diversification boom of the 1960's, based on naive investor interpretations of price/earnings ratios. Nevertheless, as discussed by Shleifer and Vishny (2003), the misvaluation approach to takeovers has had a low profile among academics relative to efficient markets approaches. Shleifer and Vishny offer a theory in which irrational shifts in investor sentiment affect takeover decisions. In their setting there are no synergies, managers behave rationally, and takeovers are driven purely by irrational stock market misvaluation.

In this paper, we examine empirically the misvaluation hypothesis of takeovers: that market inefficiency has important effects on takeover activity. We test several of the predictions of Shleifer and Vishny (2003), as well as several further predictions of the misvaluation hypothesis developed intuitively here to further distinguish it from alternative approaches.

\footnotetext{
${ }^{1}$ On the financing side, several authors have provided evidence that firms time new equity issues to exploit market misvaluation, and manage earnings to induce such misvaluation - see, e.g., Ritter (1991), Loughran and Ritter (1995), Rajan and Servaes (1997), Teoh, Welch, and Wong (1998a, 1998b), Teoh, Wong, and Rao (1998) and Baker and Wurgler (2000)). Recent evidence suggests that inefficient market valuations influence levels of investment (Polk and Sapienza (2003)) and the sensitivity of investment to cash flow (Baker, Stein, and Wurgler (2003))
} 
The misvaluation hypothesis holds that bidders try to profit either by buying undervalued targets for cash at a price below fundamental value; or by paying equity for targets that, even if overvalued, are less overvalued than the bidder. As argued by Shleifer and Vishny, target overvaluation encourages target management to voluntarily accept expropriative offers in order to 'cash out.' Bidder and target misvaluation measures should affect expropriation opportunities and managerial incentives, and therefore transaction characteristics, including the means of payment (stock versus cash), the form of the offer (merger versus tender offer), the bid premium, hostility of the target to the offer, the success of the bid, and event period returns. The misvaluation hypothesis also implies that bidders will tend to be overvalued relative to targets, especially among stock offers, in which it is the bidder's relative overvaluation that enables its expropriation of target assets.

An alternative theory, which we call the $Q$ hypothesis of takeovers, focuses on how takeover can cause target assets to be employed either more or less efficiently. These changes may derive from elimination of wasteful target behavior, from better bidder investment opportunities, or alternatively from the empire-building propensities of bidders. $^{2}$ High market value is an indicator that a firm is 'good,' i.e., is well-run or has good business opportunities, as it reflects the extent to which the firm has succeeded in creating shareholder value from past investment. Takeovers of bad targets by good bidders tend to improve efficiency more than takeovers of good targets by bad bidders. The detailed predictions of the misvaluation and $Q$ hypotheses are developed in Section 2 .

We define misvaluation as the discrepancy between the current market price and fundamental value. To estimate this discrepancy, we apply two contemporaneous nonmarket measures of fundamental value: book value, and residual income value as derived from the model of Ohlson (1995). Our misvaluation proxies are therefore the ratio of book value of equity to price (hereafter $B / P$ ), and the ratio of residual-income value to price (hereafter $V / P$ ).

Previous papers have related $B / P$ or allied variables to takeover characteristics, often with much older or restricted samples. There are very few findings about $B / P$ in relation to takeover characteristics that use data from the last decade, the period of by far the largest takeover wave in history. The total value of transactions (2001 dollars) from the

\footnotetext{
${ }^{2}$ Our development of the $Q$ hypothesis is based upon the work on Tobin's $Q$ and takeovers of Lang, Stulz, and Walkling (1989), Servaes (1991), and Jovanovic and Rousseau (2002), and on agency, growth and takeovers of Morck, Shleifer, and Vishny (1990). Another possible alternative, the financing constraint/debt capacity hypothesis, can be distinguished by controlling for leverage; see Section 2.
} 
last 8 years of our sample, $1993-2000$ of $\$ 4.35$ trillion is much greater than the total value of transactions in the preceding 15 years of our dataset of $\$ 1.18$ trillion. Indeed, the transaction value from 1997-2000 alone is $\$ 3.59$ trillion.

Furthermore, most past tests condition on what are, according to the misvaluation hypothesis, dependent variables. For example, most studies condition on offer success. But if misvaluation affects success and so does a transaction characteristic (such as friendly versus hostile, merger versus tender, or cash versus equity), then conditioning on success induces a correlation between misvaluation and the characteristic even if misvaluation has no effect on the characteristic.

In this paper we use two further means to test the misvaluation hypothesis and distinguish it from alternative theories. First, we test a wider set of theoretical predictions about misvaluation and takeover characteristics. We thereby expose the theories to possible refutation from different directions. Second, we apply a purer measure of misvaluation, contemporaneous $V / P$.

$B / P$ has been viewed as a mispricing proxy in several asset pricing and corporate finance contexts. However, book value reflects only historical costs rather than forwardlooking prospects. In consequence, $B / P$ (or closely allied variables such as the reciprocal of proxies for Tobin's $Q$ ) is a proxy not just for misvaluation, but for genuine information about the ability of the firm to generate high returns on its investments. $B / P$ or allied variables have therefore also been applied in many corporate finance papers as proxies for firm growth opportunities or managerial effectiveness.

An alternative, forward-looking measure of firm fundamental value derives from the residual income model, which has been widely applied in the accounting literature. ${ }^{3}$ Residual income value $(V)$ reflects expected future performance by incorporating analysts' forecasts of future earnings in addition to book value. Since the numerator of $V$ captures future earnings prospects, $V / P$ filters out the extraneous information about growth and managerial agency problems much better than $B / P . V / P$ therefore provides a relatively pure measure of misvaluation. Thus, the misvaluation hypothesis offers a rich set of distinctive empirical implications about $V / P$.

However, it is unlikely that analyst forecasts perfectly filter information about growth from the market price. To further control for growth, we examine the effects of bidder and target $V / P$ after controlling for bidder and target $B / P$. Focusing solely on this incre-

\footnotetext{
${ }^{3}$ Support for the use of $V / P$ as a mispricing proxy is provided by Frankel and Lee (1998), Lee, Myers, and Swaminathan (1999), and Ali, Hwang, and Trombley (2003); a corporate finance application is provided by D'Mello and Shrof (2000).
} 
mental effect provides a double safeguard for growth or agency-related effects. However, such a test is overly stringent. The evidence from past literature (see Section 3) suggests that $B / P$ is informative about misvaluation, both on its own and incrementally to $V / P$. So controlling for $B / P$ is likely to remove not only growth, but part of the misvaluation effect we seek to measure. We therefore provide evidence about both $B / P$ and $V / P$ in univariate and multivariate tests. Subsection 3.1 discusses in greater depth the motivation for and differences between $B / P$ and $V / P$ as misvaluation proxies.

To address the misvaluation hypothesis systematically, we consider statistical evidence during the period January 1, 1978 through December 31, 2000 about the relation of misvaluation measures to takeover-related decisions and market reactions. We summarize the main qualitative findings in the Appendix Table.

For each cross-sectional prediction we have four tests (univariate and multivariate, $B / P$ and $V / P)$, with the $V / P$ tests highly stringent. The particular findings in some cases differ across tests, but the main thrust of our findings is as follows. (We mention the $Q$ hypothesis only for those tests for which it makes an unambiguous prediction.)

Bidders on average have significantly lower $B / P$ and $V / P$ ratios (indicating greater measured overvaluation) than their targets, consistent with the misvaluation hypothesis. ${ }^{4}$ Consistent with the misvaluation hypothesis, this effect is present in both cash and stock offers, is stronger among stock offers, and is present in both mergers and tender offers.

Greater measured target overvaluation is generally associated with a greater (smaller) probability that equity (cash) is the sole means of payment. This evidence is consistent with bidders making friendly equity offers to overvalued targets (Shleifer and Vishny (2003)) and using equity offers to leave more target overvaluation on the shoulders of target shareholders.

Targets with greater measured overvaluation (less undervaluation) are less likely to be hostile to the bid, are less likely to receive tender offers rather than merger bids, have a higher probability of being successfully acquired, earn lower announcement date abnormal returns, and tend to receive lower bid premia. ${ }^{5}$ The misvaluation hypothesis predicts these relationships because undervalued targets tend to be hostile to expropriative bids, implying hostile tender offer rather than friendly merger bid, higher premia

\footnotetext{
${ }^{4}$ Andrade, Mitchell, and Stafford (2001) and Jovanovic and Rousseau (2002) find that target exceeds bidder $B / P$ among offers that subsequently succeeded.

${ }^{5}$ The $B / P$ finding on target stock returns is consistent with the findings of Lang, Stulz, and Walkling (1989) and Servaes (1991) in earlier samples that condition on subsequent offer success; the premium finding is consistent with that of Walkling and Edmister (1985) in an early sample.
} 
relative to the depressed market stock price, and thereby higher target announcement date returns. In contrast, managers of overvalued targets are willing to accept offers to 'cash out' (Shleifer and Vishny (2003)). The $Q$ hypothesis shares the predictions about premia and abnormal returns, because greater gains from takeover are generated when targets are poorly-run or have poor opportunities (high $B / P$ ), and some of this gain is shared with target shareholders.

Higher measured target overvaluation is associated with a lower bidder return only in the univariate test. This univariate (but not the multivariate) finding supports the misvaluation hypothesis because more overvalued target should generate lower gains for bidders; and, for $B / P$, supports the $Q$ hypothesis because well-run or rapidly growing targets should generate lower gains for bidders (Lang, Stulz, and Walkling (1989), Morck, Shleifer, and Vishny (1990) and Servaes (1991)).

Turning to the effects of bidder valuations on transaction characteristics, we find that bidders with higher estimated overvaluation are more likely to use stock and less likely to use cash as the sole consideration. This is consistent with bidders profiting by exchanging overvalued equity for more valuable target assets. ${ }^{6}$

With the $B / P$ measure, more overvalued bidders tend to pay higher premia (with more consistent significance in the equity subsample). This evidence is consistent with the misvaluation hypothesis, because overvalued bidders are willing to pay a nominally higher price using overvalued equity as currency, and find it easier to raise capital for a cash offer. It is also consistent with the $Q$ hypothesis, because better bidders generate bigger gains which are in part shared with target shareholders. There is no significant $V / P$ effect; this finding fails to support the misvaluation hypothesis.

It is striking that greater estimated bidder overvaluation (lower $B / P$ and $V / P$ ) is strongly associated with lower bidder announcement-date abnormal stock returns. This is consistent with the misvaluation hypothesis, which predicts that the stock reaction will partly correct prior misvaluation. The $B / P$ finding is directly opposed to the $Q$ hypothesis, which predicts that offers by well-run bidders should generate higher bidder stock returns. Our finding also contrasts sharply with evidence from earlier time periods. ${ }^{7}$ This contrast suggests that agency or other resource reallocation effects may

\footnotetext{
${ }^{6} \mathrm{An}$ association between bidder $B / P$ (or $Q$ ) and means of payment conditional upon subsequent offer success was established by Martin (1996) and Rau and Vermaelen (1998). Our finding that undervaluation as measured by $V / P$ predicts the use of cash rather than equity provides evidence that misvaluation matters above and beyond any possible growth-related effects.

${ }^{7}$ In Lang, Stulz, and Walkling (1989) and Servaes (1991), announcement-period bidder returns in successful offers were higher when bidders had high Tobin's $Q$ measures; $B / P$ is inversely related to $Q$
} 
have been more important during the merger boom of the 1980's than in more recent years.

Overall, the evidence in this paper generally confirms a wide range of predictions for the misvaluation hypothesis. The $B / P$ evidence on the whole strongly supports the misvaluation hypothesis. The $Q$ hypothesis offers a narrower range of predictions about $B / P$ - in relation to bid premia and announcement date returns - several of which are confirmed. In the case where the two hypotheses make directly opposing predictions (the relation between bidder $B / P$ and bidder announcement period return), it is the misvaluation prediction that is confirmed. The $V / P$ evidence overall provides substantial additional support for the misvaluation hypothesis. These findings do not rule out the possibility of important growth/agency effects. However, the evidence provides clearer support for the proposition that irrational market misvaluation affects the behavior of both bidders and targets in takeover contests.

There has also been some recent independent work on transaction-level valuations and means of payment in takeovers. Ang and Cheng (2003) use an industry-relative book-to-price ratio, and a residual income measure to examine how misvaluation affects the means of payment in takeovers, and long-run abnormal return performance of the combined firm. Rhodes-Kropf, Robinson, and Viswanathan (2003) examine how firm and industry valuations relate to means of payment and merger frequency. In this paper, in order to expose the misvaluation hypothesis to possible disconfirmation on several fronts, we examine a wider set of takeover characteristics.

The remainder of the paper is structured as follows. Section 2 develops the predictions of the misvaluation hypothesis. Section 3 describes the data and method of the study. Section 4 describes univariate tests of the relation between bidder or target misvaluation on different transaction characteristics. Section 5 describes multivariate tests. Section 6 concludes.

\section{Predictions}

We develop a set of implications of the misvaluation hypothesis for the relation of contemporaneous measures of misvaluation, $B / P$ and $V / P$ to takeover characteristics, drawing insights from the theory of Shleifer and Vishny (2003). We then contrast the implications of the misvaluation hypothesis with those of alternative theories.

In Shleifer and Vishny's approach, managers rationally value firms, and investors do (see also footnote 13). 
not. Cash takeovers result from the efforts of bidders to acquire undervalued targets at prices below fundamental value. Equity takeovers result from the efforts of highly overvalued bidders to trade their assets for less overvalued target assets, thereby achieving a favorable real exchange ratio. Target managers accept such offers if the target is also overvalued, as takeover gives target management the chance to 'cash out' of illiquid stock or option holdings. More generally, the misvaluation hypothesis reflects the insight that the willingness of target management to cash out should tend to be greater when the target is less undervalued (or more overvalued). ${ }^{8}$

As discussed above, the only way a stock bidder can profit from misvaluation is to acquire a less overvalued (but still overvalued) target. The bidder-target valuation differential will tend to be smaller for cash offers, because even a bidder that is undervalued relative to its target can sometimes profit by buying an undervalued target cheaply. Nevertheless, even cash bidders should on average be overvalued relative to their targets, for two reasons. First, the ability to raise capital cheaply loosens a firm's cash constraints, so overvaluation encourages making a cash bid over no bid. Second, cash bidders profit by acquiring undervalued targets.

We therefore have:

\section{Prediction 1 Bidder versus Target Misvaluation}

$i$. Both equity and cash bidders are on average overvalued relative to their targets.

ii. The average valuation difference between bidders and targets is greater for equity than for cash offers.

The reasoning underlying Prediction 1 directly implies that bidders are overvalued relative to targets in a general sample as well. Furthermore, the arguments for bidder overvaluation relative to targets (bidder overvaluation eases raising capital, and relative overvaluation generates profits in equity bids) applies to both merger bids and tender offers. So we also have:

\section{Prediction 1 (continued)}

iii. In both tender offers and merger bids, acquirers are on average overvalued relative to their targets.

As discussed earlier, in Shleifer and Vishny (2003) overvalued targets receive equity

\footnotetext{
${ }^{8} \mathrm{We}$ do not insist that voluntary acceptance occur if and only if a target is overvalued. In practice the manager of an undervalued target may be pressured to sell by shareholders enthusiastic about the offered premium, or induced to sell by bidders offering indirect side payments. Such effects smooth the relationship between target valuation and the probability that the target is willing to sell the firm to an expropriative bidder.
} 
offers (since overvalued target management is willing to cash out even to relatively overvalued equity bidders). There is a further reason: ceteris paribus, the more overvalued (or less undervalued) the target, the stronger the incentive of the bidder to leave part of the target's misvaluation on the shoulders of target shareholders. Paying with equity of the merged firm does so. We therefore have:

\section{Prediction 2 Effects of Target Misvaluation}

Greater target overvaluation is associated with:

i. Greater use of stock rather than cash as a means of payment.

An immediate corollary of Prediction 2.i. is that equity targets are on average overvalued relative to cash targets.

Since cash offers exploit unwilling, undervalued targets, whereas less undervalued or more overvalued targets are more willing to 'cash out' to relatively overvalued equity offers, higher target overvaluation should be associated with a greater likelihood of transaction friendliness. Also, since merger bids require management approval whereas tender offers can bypass management, hostility is associated with tender offer rather than merger bid. ${ }^{9}$ Finally, since target overvaluation encourages target management acceptance, it should also improve the probability of offer success. We therefore have:

Prediction 2 (continued) Greater target overvaluation is associated with:

ii. A lower probability that the offer is hostile;

iii. A lower probability that the offer is a tender offer rather than a merger bid; and iv. A greater probability of success.

Furthermore, greater undervaluation increases a target's incentive to fight to maintain a premium (or avoid a discount) relative to fundamental value. This has the effect of boosting the premium relative to the market price. We therefore have:

Prediction 2 (continued) Greater target overvaluation is associated with:

v. A lower bid premium.

Despite Prediction 2.v, the misvaluation hypothesis also predicts:

Prediction 2 (continued) Greater target overvaluation is associated with:

vi. Lower bidder announcement date stock returns.

The reason is that in equity offers, the bidder profits precisely from being more overvalued

\footnotetext{
${ }^{9}$ The use of cash can expedite a hostile transaction by avoiding the SEC filing requirements associated with equity issuance, and, perhaps, by making it easier for investors to evaluate the offer.
} 
than its target; and in cash offers, target undervaluation is the source of bidder profits. For cash offers, this effect is moderated (but not reversed) by the fact that as target undervaluation increases, so does target opposition. Since equity offers are on the whole friendly, this moderating effect is relatively weak. Thus, the effect in Prediction 2.vi should be driven primarily by equity rather than cash offers.

Given a bid, greater bidder overvaluation increases the incentive to pay with equity rather than cash by reducing the fundamental cost per dollar of market value offered as consideration. ${ }^{10}$ We therefore obtain:

\section{Prediction 3 Effects of Bidder Misvaluation}

Greater bidder overvaluation is associated with:

$i$. Greater use of stock rather than cash as a means of payment.

An immediate corollary of Prediction 3.i is that stock bidders are overvalued relative to cash bidders.

Greater bidder overvaluation does not necessarily increase the likelihood that the offer will be friendly, owing to opposing effects. On the one hand, greater bidder overvaluation makes it more likely that the bidder makes a relatively overvalued stock offer to an overvalued target rather than a hostile cash offer to an undervalued target (Shleifer and Vishny (2003)). Furthermore, less cash constrained firms can afford to pay more, reducing hostility. On the other hand, among equity offers, greater bidder overvaluation ceteris paribus increases the expropriation of target assets. Among cash offers, greater bidder overvaluation may make the bidder more vulnerable to public disparagement by the target (which, if credible, may constrain the bidder's ability to raise capital); Schwert (2000) analyzes publicity as part of the takeover bargaining process). These considerations should tend to increase target opposition. ${ }^{11}$ Similarly, the prediction is ambiguous as to whether higher bidder overvaluation promotes merger bid versus tender offer, hostility versus friendliness, and higher versus lower probability of success.

\footnotetext{
${ }^{10}$ See Rau and Vermaelen (1998) and Shleifer and Vishny (2003). Overvaluation encourages making either a stock or a cash offer relative to no offer. The incentive of an overvalued firm to make an equity offer is direct: the ability to pay with overvalued equity. Cash bids are encouraged indirectly; the ability of an overvalued firm to raise equity capital cheaply relaxes capital constraints. Since performing a separate equity issue in addition to a takeover bid is costly (investment banking fees, management time, and possible offer delay), overvaluation should encourage stock over cash offers.

${ }^{11}$ Target management will oppose expropriation to the extent that its incentives are aligned with the interests of its shareholders; or if the bidder stock or perquisites that target management will receive upon acquisition are imperfectly liquid, so that bidder overvaluation imposes a cost upon target management.
} 
Overvaluation should loosen capital constraints, so overvalued cash bidders should be able to afford to offer a higher premium in order to ensure success. Furthermore, an overvalued equity offer is less attractive to target management than a corresponding cash premium, so overvaluation increases the pressure on an equity bidder to boost the premium and thereby target stock returns. We therefore have:

Prediction 3 (continued) Greater bidder overvaluation is associated with:

ii. Higher bid premia.

iii. Higher target announcement date stock returns.

The misvaluation hypothesis further implies that greater bidder overvaluation should be associated with lower (more negative) returns to bidders, for two reasons. First, takeover bids are salient events that call attention to the firms involved. To the extent that more careful analysis helps investors correct misvaluation, the stock price reaction will tend to oppose the prior misvaluation. ${ }^{12}$ Second, as discussed above, overvalued bidders are predicted to offer high bid premia to targets. Relatedly, in the case of equity offers, the market will tend to believe mistakenly that the bidder is paying too much (since the market overvalues the equity being offered more than it overvalues the target assets). For both reasons, we have:

\section{Prediction 4 Bidder Misvaluation and Announcement Date Returns}

Greater bidder overvaluation is associated with lower bidder announcement date stock returns.

Similarly, the misvaluation hypothesis implies that more overvalued targets should tend to have more negative announcement period returns, for three reasons. First, as with misvalued bidders, an offer draws attention to the target, partly correcting prior overvaluation. Second, overvalued targets tend to receive low bid premia (Prediction 2.vi). Third, the more the market overvalues (or less it undervalues) target assets, the less attractive a given premium seems to investors. We therefore have:

\section{Prediction 5 Target Misvaluation and Announcement Date Returns}

Greater target overvaluation is associated with lower target announcement date abnormal returns.

We test these predictions using contemporaneous measures of misvaluation, $B / P$

\footnotetext{
${ }^{12}$ Such partial correction of prior misvaluation is consistent with a body of evidence about various types of discretionary corporate actions that post-event long-run abnormal returns tend to be of the same sign as initial event-date reactions; this literature is reviewed in Hirshleifer (2001).
} 
and $V / P$.

\section{Alternative Theories}

Two alternative possible explanations for a relation between $B / P$ and takeover characteristics are what we call the $Q$ hypothesis of takeovers (Lang, Stulz, and Walkling (1989), Servaes (1991), and Jovanovic and Rousseau (2002)), and the financing constraint/debt capacity hypothesis. The $Q$ hypothesis asserts that takeovers reallocate target assets to different uses. These uses can generate higher or lower payoffs depending on the quality of bidder and target management, and on the business opportunities of bidder and target firms.

In this approach, Tobin's $Q$, proxied by the ratio of firm market value to book value, is an indicator of the degree to which a firm has good opportunities to create shareholder market value from invested resources. Takeover bidders can create value by making better use of target assets, possibly owing to higher managerial quality. On the other hand, poorly run bidders may waste resources on takeovers and make poor use of target assets. For example, bidders may waste their free cash flow (Jensen (1986)), or make empire-building equity offers.

Thus, the $Q$ hypothesis predicts that greater total gains are generated in acquisitions involving bad targets and good bidders than in transactions involving good targets and bad bidders. These larger gains are shared between bidder and target. So higher bidder valuation and lower target valuation are predicted to be associated with high bidder and target returns (see Lang, Stulz, and Walkling (1989), and Servaes (1991)), and (we further predict) higher bid premia.

When proxies for $Q$ are high, equity $B / P$ tends to be low, so our $B / P$ is an inverse measure of the bidder or target's ability to create value from existing assets. ${ }^{13}$ The $Q$ hypothesis predictions that higher bidder valuations are associated with higher bid premia and target returns are therefore consistent with the prediction for $B / P$ of Predictions 3.ii and 3.iii of the misvaluation hypothesis. The prediction that higher target valuation is associated with lower bidder returns is also consistent with the prediction for $B / P$ of Prediction 2.vi of the misvaluation hypothesis. (An alternative agency story with essentially the same empirical implication is that bad bidders like to acquire rapidly growing targets but do not profit by doing so [see Morck, Shleifer, and Vishny (1990)].)

The $Q$ approach is also consistent with Prediction 5's implication for $B / P$, because

\footnotetext{
${ }^{13}$ Empirical studies on Tobin's $Q$ and takeovers use $Q$ proxies relating to the ratio of total asset rather than equity values. However, equity $B / P$ is highly correlated with asset $B / P$; furthermore, our multivariate tests include leverage controls.
} 
there is less room to improve a target that is already well-run (low $B / P$ ), implying lower average target announcement date abnormal returns. Of course, even in those cases where both theories make consistent predictions, empirical testing is important since the data could easily reject both hypotheses.

The prediction that higher bidder valuations are associated with higher bidder returns is directly opposed to the prediction for $B / P$ of Prediction 4 of the misvaluation hypothesis. The relation between bidder $B / P$ and bidder returns is therefore particularly relevant in distinguishing the alternative hypotheses.

The $Q$ hypothesis does not offer predictions about how either bidder or target valuations relate to hostility, nor to related takeover characteristics such as merger bid versus tender offer, cash versus equity, or probability of offer success. For example, in their hypotheses and tests, Lang, Stulz, and Walkling (1989), Morck, Shleifer, and Vishny (1990), Servaes (1991), and Jovanovic and Rousseau (2002)) do not distinguish between hostile and friendly offers, and their predictions are the same for tender offers versus mergers, and for cash versus equity bids. ${ }^{14}$

Under the $Q$ hypothesis there is no presumption as to whether bidder or target $Q$ is higher. Takeovers can involve empire-building purchases of high- $Q$ targets by low- $Q$ bidders, but also value-improving purchases of low- $Q$ targets by high- $Q$ bidders. Thus, the $Q$ theory makes no prediction about relative valuations corresponding to the misvaluation hypothesis Predictions 1.i-1.iii.

Overall, the misvaluation hypothesis offers a wider range of implications than the $Q$ hypothesis. The two approaches overlap on several $B / P$ predictions about premia and announcement date returns, and are in sharp conflict over the relation between bidder valuation and bidder returns. The predictions of the misvaluation hypothesis about $V / P$ are distinctive. Multivariate $V / P$ tests that control for $B / P$ provide a backstop control for growth-related effects, and provide very stringent tests for misvaluation effects.

Theories of financing and capital structure predict that leverage levels will be related to firms' growth opportunities, so there is ex ante reason to expect leverage and $B / P$ to be correlated. The financing constraint/debt capacity hypothesis holds that leverage, financing constraints and growth opportunities influence bidder behavior. For example, a highly leveraged bidder or a high growth bidder may be more inclined to pay with equity than with cash (on the latter point, see Martin (1996)). In order to focus on

\footnotetext{
${ }^{14}$ Disciplinary acquisitions presumably tend to involve low valuation targets. However, since, under the $Q$ approach, offers involving high valuation bidders and low valuation targets generate relatively high gains to be shared, it is not obvious that they are necessarily hostile on the whole.
} 
the effects of misvaluation, we therefore control for leverage in our multivariate tests. Since $V / P$ is purified of much of the growth effects contained in $B / P$, our tests with $V / P$ should be much less subject to an interpretation in terms of financing constraints and growth. Our tests of the effects of $V / P$ after controlling for $B / P$ provide an even stronger control.

\section{Data and Methodology}

Our sample of takeover bids is obtained from Security Data Corporation (SDC) U.S. mergers and acquisitions database between 1978-2000. Our sample contains both successful and unsuccessful offers subject to the following selection criteria:

- Both the acquiring and target firms are traded on NYSE, AMEX, or NASDAQ and their price and return data are available over the eleven-day period around the acquisition announcement from the Center for Research in Security Prices (CRSP).

- The value of the transaction is $\$ 10$ million or more.

- The offer is announced between January 1, 1978 and December 31, 2000.

- If an acquirer makes multiple attempts to acquire the same target, only the first announcement is included in the sample.

The final sample includes 2,922 successful and 810 unsuccessful acquisition bids. ${ }^{15}$ Table 1 reports the annual breakdown of the acquisitions by acquisition outcome, method of payment, mode of acquisition, hostility of the transaction, and whether the bidder and the target are in the same industry.

Accounting data for calculating book value and residual income model value (described below) are from COMPUSTAT. Earnings forecasts needed for calculating the residual income model intrinsic values are obtained from I/B/E/S. To maintain sample size, we do not exclude a transaction from the overall sample just because of missing accounting or $\mathrm{I} / \mathrm{B} / \mathrm{E} / \mathrm{S}$ data items.

\footnotetext{
${ }^{15}$ The bid premium is defined as the bid price of the offer divided by the market price of the target 5 days before the announcement. If the bid premium is less than $-50 \%$ or greater than $200 \%$, then we treat it as missing. We require that target stock price at the time of the announcement exceed $\$ 3$. To ensure data accuracy, for successful acquisitions, we compare the CRSP delisting date of the target and the SDC effective date. If the difference between the two dates is greater than 40 trading days, then the acquisition is deleted from the sample.
} 


\subsection{Motivation for and Calculation of Mispricing Proxies}

The reliability of the inferences we draw about the misvaluation hypothesis of takeover markets rests upon the quality of our misvaluation proxies, $B / P$ and $V / P$. The validity of our approach, however, does not require that either book value or residual income value be a better proxy for rational fundamental value than market price. We merely require that these measures contain substantial incremental information about fundamentals above and beyond market price. We would expect them to do so if a significant portion of variations in market price derives from misvaluation.

A possible alternative means of testing the misvaluation hypothesis is to estimate long-run stock returns. A stock that is inefficiently mispriced should eventually earn abnormal returns when misvaluation is corrected. Thus, long-run abnormal returns provides an indirect measure of misvaluation. Several authors have examined the long-run abnormal returns to successful acquirers, and how these returns relate to means of payment and pre-offer valuation measures. ${ }^{16}$ Such studies generally focus on merged firms, and therefore do not measure how mispricing relates to offer success, nor on the distinct effects of bidder versus target misvaluations. Furthermore, there is much controversy about how to interpret long-run post-event returns, which may reflect rational risk premia. ${ }^{17}$ A key advantage of tests based on contemporaneous measures of misvaluation is that it does not require drawing inferences from stock returns occurring years after the takeover event.

In support of the $B / P$ proxy, an extensive literature demonstrates that firms' $B / P$ ratios are remarkably strong and robust predictors of the cross-section of subsequent onemonth returns (see, e.g., the review of Daniel, Hirshleifer, and Teoh (2002)). Psychologybased theoretical models imply that $B / P$ is a proxy for misvaluation, and thereby will predict subsequent abnormal returns (see, e.g., Barberis and Huang (2001) and Daniel, Hirshleifer, and Subrahmanyam (2001)). Market values reflect both mispricing, risk, and differences in true unconditional expected cash flows (or scale). Book value can help filter out irrelevant scale differences, and so $B / P$ can provide a less noisy measure

\footnotetext{
${ }^{16}$ See, for example, Franks, Harris, and Titman (1991), Loughran and Vijh (1997), Rau and Vermaelen (1998), Dong, Hirshleifer, Richardson, and Teoh (2002), and Moeller, Schlingemann, and Stulz (2003a, 2003b).

${ }^{17}$ Some recent overviews include Fama (1998), Loughran and Ritter (2000), and Daniel, Hirshleifer, and Teoh (2002)). The outcomes of long-run return studies are often sensitive to the empirical method, including the choice of the return benchmark, the method for compounding returns, and the treatment of cross-event return correlations (Barber and Lyon (1997), Mitchell and Stafford (2000), Fama (1998), and Loughran and Ritter (2000)).
} 
of mispricing (see Daniel, Hirshleifer, and Subrahmanyam (2001)). On the other hand, $B / P$ is a natural proxy for risk as well. An active debate remains about the extent to which $B / P$-based return predictability reflects a rational risk premium or correction of mispricing. ${ }^{18}$

The association of $B / P$ with subsequent abnormal returns suggests that there is a misvaluation or risk component to the variation of $B / P$. However, $B / P$ has been used as a proxy not just for misvaluation or for risk, but also for growth opportunities and for the degree of information asymmetry (Martin (1996)). Furthermore, proxies for Tobin's $Q$ that are highly correlated with $B / P$ have been employed to measure the quality of corporate growth opportunities and the degree of managerial discipline. A further source of noise in $B / P$ for our purposes is that book value, the numerator of $B / P$, is influenced by firm and industry differences in accounting methods.

We calculate $B / P$ as a ratio of equity rather than total asset values, because it is equity rather than total misvaluation that is likely to matter for takeover decisions; a similar point applies for $V / P$. This would be the case, for example, for a misvalued bidder that contemplates using equity shares to purchase the equity shares of a target firm. Similarly, a potential bidder that is overvalued is presumably more likely to raise equity rather than debt capital to finance a takeover bid.

There is also strong support for $V / P$ as an indicator of mispricing. Lee, Myers, and Swaminathan (1999) find that aggregate residual income values predict one-monthahead returns on the Dow 30 stocks better than aggregate $B / P$. Frankel and Lee (1998) find that $V$ is a better predictor than book value of the cross-section of contemporaneous stock prices, and that $V / P$ is a predictor of the one-year-ahead cross-section of returns. Furthermore, Ali, Hwang, and Trombley (2003) report that the abnormal returns associated with high $V / P$ are partially concentrated around subsequent earnings announcements. They also report that after controlling for a large set of possible risk factors (including beta, size, book/market, residual risk, and loadings from the Fama and French (1996) three-factor model), $V / P$ continues to predict future returns significantly. These findings make $V / P$ an attractive index of mispricing. ${ }^{19}$

\footnotetext{
${ }^{18}$ See, e.g., Fama and French (1996) and Daniel and Titman (1997), and the review of Daniel, Hirshleifer, and Teoh (2002). Some more recent empirical papers addressing factor risk versus mispricing as explanations for the $B / P$ premium include Griffin and Lemmon (2002), Cohen, Polk, and Vuolteenaho (2002) and Vassalou and Xing (2003).

${ }^{19}$ For example, D'Mello and Shrof (2000) apply $V / P$ to measure mispricing of equity repurchasers. To test the hypothesis that private information influences the takeover bidders' choice of means of payment, Chemmanur and Paeglis (2002) use ex post realized earnings as inputs in valuation models to construct proxies for private signals. In contrast, our focus is on measuring market pricing errors
} 
There are other possible indices of misvaluation. An alternative measure which we do not examine is the earnings/price ratio. Earnings price ratios have several drawbacks for our purposes. First, earnings/price is not as strong a predictor of month-ahead stock returns as book/market (see, e.g., Fama and French (1996)), suggesting that it is a less accurate measure of mispricing. Second, short-term earnings fluctuations will tend to shift earnings/price even if the degree of misvaluation is unchanged. Third, and relatedly, negative earnings are more common than negative book values, leading more frequently to negative values of earnings/price.

The residual income model has at least two important advantages over book value as a fundamental measure. First, it is designed to be invariant to accounting treatments (to the extent that the 'clean surplus' accounting identity obtains; see Ohlson (1995)), making $V / P$ less sensitive to such choices. Second, in addition to the backward-looking information contained in book value, it also reflects analyst forecasts of future earnings.

On the other hand, if analyst forecasts are infected with biases that are correlated with market misperceptions, the residual income value may share some of the misvaluation contained in market price. This could arise if investors are misled by strategic biases in analysts' forecasts, or if analysts and investors are subject to common psychological biases. The cancellation of common biases can weaken $V / P$ as a proxy for misvaluation. This biases the results of tests using $V / P$ toward finding no effect.

These considerations - the high extraneous variation in $B / P$ as an indicator of mispricing, and the possibility of partial cancellation of mispricing in the $V / P$ measuresuggest that either proxy may give an incorrect null result even if misvaluation drives the takeover market. Furthermore, $B / P$ can proxy for extraneous effects such as growth opportunities or managerial discipline. Since neither measure is perfect, it is informative to include both $B / P$ and $V / P$ measures of misvaluation in our tests.

In our sample, the correlation of $B / P$ with $V / P$ is fairly low- 0.33 for bidders and 0.20 for targets. Thus, $V / P$ potentially offers useful independent information beyond $B / P$ regarding misvaluation. This is to be expected, as much of the variation in book/market arises from differences in growth opportunities or in managerial discipline that do not necessarily correspond to misvaluation.

Turning to procedure, we calculate the $B / P$ proxy as the ratio of book value of equity to market value of equity. Each month for each stock, book equity is measured at the end of the prior fiscal year, using the definition as in Baker and Wurgler (2002).

relative to publicly available information. We therefore calculate our misvaluation proxies solely using contemporaneous information (current price, book value, and analyst forecasts). 
Market value of equity is measured at the end of the month.

Our estimation procedure for $V / P$ is similar to that of Lee, Myers, and Swaminathan (1999). For each stock in month $t$, we estimate the residual income model (RIM) price, denoted by $V(t)$. With the assumption of "clean surplus" accounting, which states that the change in book value of equity equals earnings minus dividends, the intrinsic value of firm stock can be written as the book value plus the discounted value of an infinite sum of expected residual incomes (see Ohlson (1995)),

$$
V(t)=B(t)+\sum_{i=1}^{\infty} \frac{E_{t}\left[\left\{R O E(t+i)-r_{e}(t)\right\} B(t+i-1)\right]}{\left[1+r_{e}(t)\right]^{i}},
$$

where $E_{t}$ is the expectations operator, $B(t)$ is the book value of equity at time $t$ (negative $B(t)$ observations are deleted), $R O E(t+i)$ is the return on equity for period $t+i$, and $r_{e}(t)$ is the firm's annualized cost of equity capital.

For practical purposes, the above infinite sum needs to be replaced by a finite series of $T-1$ periods, plus an estimate of the terminal value beyond period $T$. This terminal value is estimated by viewing the period $T$ residual income as a perpetuity. Lee, Myers, and Swaminathan (1999) report that the quality of their $V(t)$ estimates was not sensitive to the choice of the forecast horizon beyond three years. The residual income valuations are also likely to be less sensitive to errors in terminal value estimates than in a dividend discounting model; pre-terminal values include book value, so that terminal values are based on residual earnings rather than full earnings (or dividends). ${ }^{20}$ Of course, the residual income $V(t)$ cannot perfectly capture growth, so our misvaluation proxy $V / P$ does not perfectly filter out growth effects. However, since $V$ reflects forward-looking earnings forecasts, a large portion of the growth effects contained in $B / P$ should be filtered out of $V / P$.

We use a three-period forecast horizon:

$$
\begin{aligned}
V(t)= & B(t)+\frac{\left[f^{R O E}(t+1)-r_{e}(t)\right] B(t)}{1+r_{e}(t)}+\frac{\left[f^{R O E}(t+2)-r_{e}(t)\right] B(t+1)}{\left[1+r_{e}(t)\right]^{2}} \\
& +\frac{\left[f^{R O E}(t+3)-r_{e}(t)\right] B(t+2)}{\left[1+r_{e}(t)\right]^{2} r_{e}(t)}
\end{aligned}
$$

where $f^{R O E}(t+i)$ is the forecasted return on equity for period $t+i$, the length of a period is one year, and where the last term discounts the period $t+3$ residual income

\footnotetext{
${ }^{20}$ For example, D'Mello and Shrof (2000) found that in their sample of repurchasing firms, firms' terminal value was on average $11 \%$ of their total residual income value, whereas using a dividend discount model the terminal value was $58 \%$ of total value.
} 
as a perpetuity. ${ }^{21}$

Forecasted ROE's are computed as

$$
f^{R O E}(t+i)=\frac{f^{E P S}(t+i)}{\bar{B}(t+i-1)}, \quad \text { where } \bar{B}(t+i-1) \equiv \frac{B(t+i-1)+B(t+i-2)}{2},
$$

and where $f^{E P S}(t+i)$ is the forecasted EPS for period $t+i .^{22}$ We require that each of these $f^{R O E}$ 's be less than 1 .

Future book values of equity are computed as

$$
B(t+i)=B(t+i-1)+(1-k) f^{E P S}(t+i)
$$

where $k$ is the dividend payout ratio determined by

$$
k=\frac{D(t)}{\operatorname{EPS}(t)}
$$

and $D(t)$ and $E P S(t)$ are respectively the dividend and EPS for period $t$. Following Lee, Myers, and Swaminathan (1999), if $k<0$ (owing to negative EPS), we divide dividends by $(0.06 \times$ total assets $)$ to derive an estimate of the payout ratio, i.e., we assume that earnings are on average $6 \%$ of total assets. Observations in which the computed $k$ is greater than 1 are deleted from the study.

The annualized cost of equity, $r_{e}(t)$, is determined as a firm-specific rate using the CAPM, where the time- $t$ beta is estimated using the trailing five years (or, if there is not enough data, at least two years) of monthly return data. The market risk premium assumed in the CAPM is the average annual premium over the riskfree rate for the CRSP value-weighted index over the preceding 30 years. Any estimate of the CAPM cost of capital that is outside the range of $3 \%-30 \%$ (less than $1 \%$ of our estimates) is winsorized to lie at the border of the range. Previous studies have reported that the predictive ability of $V / P$ was robust to the cost of capital model used (Lee, Myers, and Swaminathan (1999)) and to whether the discount rate was allowed to vary across firms (D'Mello and Shrof (2000)). We checked the robustness of our main findings using the alternative constant discount rate of $12.5 \%$ (following D'Mello and Shrof (2000)). The

\footnotetext{
${ }^{21}$ Following Lee, Myers, and Swaminathan (1999) and D'Mello and Shrof (2000), in calculating the terminal value component of $V$ we assume that expected residual earnings remain constant after year 3 , so that the discount rate for the perpetuity is the firm's cost of equity capital.

${ }^{22}$ If the EPS forecast for any horizon is not available, it is substituted by the EPS forecast for the previous horizon and compounded at the long-term growth rate (as provided by I/B/E/S). If the longterm growth rate is not available from $\mathrm{I} / \mathrm{B} / \mathrm{E} / \mathrm{S}$, the EPS forecast for the first preceding available horizon is used as a surrogate for $f^{E P S}(t+i)$.
} 
results were similar to those reported here. Finally, $V / P$ is winsorized at the $1 \%$ and $99 \%$ tails.

To measure the misvaluation of acquirers and targets, we use values of $B / P$ and $V / P$ of the month prior to the acquisition announcement, to ensure that information needed for calculating the ratios are available before the announcement. The benchmark for fair valuation is not equal to 1 for either ratio, for two reasons. First, book is an historical value that does not reflect growth. Second, residual income model valuations have been found to be too low on average. Thus, our tests consider relative comparisons these misvaluation proxies: higher (lower) values of $B / P$ or $V / P$ indicate relative undervaluation (overvaluation).

\subsection{Announcement Period Returns}

Announcement period cumulative abnormal returns (CARs) are computed for the threeday period $(-1,1)$ around the announcement date (day 0). Following Fuller, Netter, and Stegemoller (2002), we employ a modified market model,

$$
C A R_{i}=r_{i}-r_{m}
$$

where $r_{i}$ is the firm- $i$ return and $r_{m}$ is the CRSP value-weighted market return, over the three-day period around the acquisition announcement.

\section{Univariate Tests}

Table 1 reports descriptive information for our 1978-2000 sample of takeover bids. As observers have often noted, there is clear evidence of cyclical patterns in acquisition activity. The number of transactions peaks in the middle of the 1980s and the latter portion of the 1990s. The average transaction value has increased toward the end of the sample period. Acquisitions were more likely to be successful in later years, and more recent acquisitions tend to be mergers. Prior to the 1990s there were more hostile offers and tender offers. The acquisition wave of the 1990s was characterized by an increased frequency of stock as a means of payment (see e.g. Andrade, Mitchell, and Stafford (2001) and Holmstrom and Kaplan (2001)). The average bid premium is $34.4 \%$ for the entire sample, and the mean abnormal return is $17.9 \%$ for target firms at the announcement of the offer. ${ }^{23}$

\footnotetext{
${ }^{23}$ These findings are similar to those of Andrade, Mitchell, and Stafford (2001), who report a median bid premium of $37.9 \%$ and mean target announcement abnormal returns of $16 \%$ in their takeover sample
} 
We next discuss whether the univariate evidence supports the misvaluation or $Q$ hypotheses. (We discuss the $Q$ hypothesis only for those takeover characteristics for which it offers predictions.) We do not stress possible leverage-related explanations for our findings, because the multivariate findings (discussed in Section 5) control for leverage and are broadly similar, with a few exceptions noted there.

Table 2 reports how under- or over- valuation is related to the acquisition mode and means of payment. Mean values of $B / P$ and $V / P$, and their differences between acquirer and target firms are reported across modes of acquisition and methods of payment. ${ }^{24}$

In Table 2 bidding firms on average tend to have lower values for $B / P$ and $V / P$ than target firms, indicating that bidders are overvalued relative to targets. The average $B / P(V / P)$ ratio for acquirers is $0.580(0.704)$ and for target firms is $0.678(0.790)$. The pairwise differences are statistically significant. This finding is consistent with Prediction 1.i of the misvaluation hypothesis. ${ }^{25}$

The $B / P$ finding extends that of Andrade, Mitchell, and Stafford (2001) and Jovanovic and Rousseau (2002), who conditioned upon offer success. Jovanovic and Rousseau (2002) propose a special case of the $Q$ hypothesis in which takeovers are generally value-increasing (thereby ruling out, for example, takeovers involving overinvestment of free cash flow). Our finding and theirs are consistent with this Panglossian version of the $Q$ approach as well as with the misvaluation hypothesis. However, more generally the $Q$ approach (as in Lang, Stulz, and Walkling (1989) and Servaes (1991)) does not specify whether good or bad transactions predominate, and is therefore ambiguous in its prediction about relative bidder and target valuations.

Prediction 1.i more specifically asserts that bidder $B / P$ and $V / P$ are lower than target $B / P$ and $V / P$ among each of cash and equity offers. This prediction is confirmed. For the 766 (362) cash transactions for which we are able to calculate $B / P(V / P)$, the bidder/target $B / P(V / P)$ differential is $-0.112(-0.058)$, highly significant for $B / P$ but only marginal for $V / P$. Among the 1246 (753) stock offers, the bidder/target $B / P$ $(V / P)$ differential is $-0.140(-0.122)$, highly significant for both measures.

Prediction 1.ii asserts that this differential will be more negative for equity than for cash offers. The misvaluation prediction is supported for $V / P, p<0.05$, but the

\footnotetext{
during 1973-98.

${ }^{24}$ Median values suggest similar inferences and are not reported. In addition, Table 2 restricts the sample to observations where $B / P$ and $V / P$ are available for both bidder and target firms.

${ }^{25}$ Subsample analysis indicates that these findings apply only within the post-1990 period. On the other hand, in a sample of 50 successful mergers in the 1950s, Gort (1969) found that acquirers on average had higher price-earnings ratios than their targets (significant in a sign test, though not at the $5 \%$ level in Gort's parametric test).
} 
$B / P$ difference is statistically insignificant, $t=0.95$ (tests not reported in table). These findings lend some support to the misvaluation hypothesis.

Prediction 1.iii asserts that in both merger bids and tender offers, bidders will be overvalued relative to their targets. This prediction is also generally confirmed. For the 2,308 $(1,226)$ merger transactions for which we are able to calculate $B / P(V / P)$, the bidder/target $B / P(V / P)$ differential is $-0.094(-0.103)$, highly significant. Among the 608 (321) tender offers, the bidder/target $B / P(V / P)$ differential is $-0.114(-0.021)$, highly significant for $B / P$, and insignificant for $V / P$.

Table 2 also indicates, consistent with an immediate corollary of Prediction 2.i, that the targets of cash offers are significantly more undervalued than the targets of stock offers; $V / P=0.833$ for cash versus 0.756 for stock (difference significant with $t=2.55$ ). (This finding derives primarily from merger bids.) Intuitively, bidders can sometimes detect target misvaluation, and are more prone to paying stock for overvalued targets in order to rest part of this overvaluation upon the shoulders of target shareholders.

Finally, consistent with an immediate corollary of Prediction 3.i, Table 2 indicates that stock bidders are on average more overvalued than cash bidders, using both $B / P$ and $V / P$ measures; $V / P=0.775$ for cash versus 0.634 for stock (difference significant with $t=6.07)$. This is consistent with the hypothesis that overvalued bidders prefer to acquire target resources using their overpriced stock as a currency, and the prediction of Shleifer and Vishny (2003).

Table 3 analyzes how the characteristics of takeover bids are related to contemporaneous measures of bidder and target misvaluation $(B / P, V / P)$. Panels $\mathrm{A}$ and $\mathrm{B}$ report the effects of target misvaluation; Panels $\mathrm{C}$ and $\mathrm{D}$ describe the effects of acquirer misvaluation. In each month, we rank firms based on their respective misvaluation ratios and form quintiles. This monthly sorting procedure ensures that any effects we identify are cross-sectional, and therefore are not driven by time-series swings in valuations and takeover characteristics.

We refer to quintile 1 , in which overvaluation is highest and $V / P$ and $B / P$ are lowest relative to other firms in the same category (other bidders, or other targets), as the top overvaluation quintile; quintile 5 , which contains high values of $B / P$ or $V / P$, indicate the strongest undervaluation. We report differences across the top and bottom overvaluation quintiles (OMU, overvalued minus undervalued) to describe how misvaluation is related to transaction characteristics. The characteristics we consider are the use of cash versus stock, tender offer versus merger bid, offer success versus failure, hostility versus friendliness of the offer, the level of the bid premium, and announcement 
period stock returns. ${ }^{26}$

Panels A and B report statistics for target firms. If target firms are resistant to selling when they are undervalued, the bidder may seek to circumvent target management and consummate swiftly by means of a cash tender offer (Prediction 2.i). Consistent with this prediction, stock is much less likely to be used as method of payment when the target is undervalued $(22.6 \%$ quintile difference in probability $(B / P) ; 17.6 \%(V / P))$, both highly significant.

Partially consistent with this reasoning, target overvaluation reduces the probability of a cash offer, but only with the $B / P$ measure. The quintile differences in the probability of cash offers are $-12.4 \%(B / P)$ and $-6.3 \%(V / P$; significant only at $10 \%$ level). These quintile results suggest that cash targets are less overvalued than equity targets.

Furthermore, consistent with Prediction 2.ii, a transaction is more likely to be hostile when the target is more undervalued (quintile difference in probability of $-7.9 \%(B / P)$ or $-5.6 \%(V / P))$. Consistent with Prediction 2.iii, a transaction is more likely to take the form of tender offer rather than merger bid when the target is more undervalued (quintile difference in probability of $-8.3 \%(B / P)$ or $-7.4 \%(V / P)$ ). There is also evidence, consistent with Prediction 2.iv that an offer is less likely to be successful when the target is undervalued (the quintile difference in probability is $9.3 \%(B / P)$ or $6.0 \%$ $(V / P)) .{ }^{27}$ Together, these findings suggest that more undervalued targets are more resistant to takeovers (consistent with the prediction of Shleifer and Vishny (2003)), and fight hard either for a higher price or to block the transaction entirely.

Consistent with Prediction 2.vi, bidder announcement returns are substantially lower when targets are more overvalued by our measures. The quintile difference for bidder CAR is $-1.4 \%(-1.8 \%)$ for $B / P(V / P)$. Furthermore, as predicted by the hypothesis, this effect derives primarily from stock acquisitions, which have quintile differences of $-1.7 \%(-2.1 \%)$ (not reported in table). ${ }^{28}$ The $B / P$ results are consistent with the $Q$ hypothesis (or agency) prediction as well, since there is less room to improve a well-run target. However, the $Q$ hypothesis does not explain the concentration of the effect in equity acquisitions.

Consistent with Predictions $2 . \mathrm{v}$ and 5 respectively, there is evidence that bid premia

\footnotetext{
${ }^{26}$ We occasionally discuss subsample findings not contained in the tables when there are differences in effects within subsamples such as cash versus equity, or merger versus tender offer. Such subsample findings must of course be interpreted with caution when categorizing based upon a dependent variable, except to the extent that theory explicitly offers predictions based on such categories.

${ }^{27}$ Schwert (2000) provides related findings in a 1975-96 sample period.

${ }^{28}$ Servaes (1991) and Morck, Shleifer, and Vishny (1990)) report evidence that, conditional on subsequent offer success, bidder gains are lower when the target has a high $Q$ or is rapidly-growing.
} 
and target announcement period returns are on average higher for more undervalued targets. ${ }^{29}$ This suggests that takeover bids on average tend to correct target mispricing. The quintile difference for bid premium is $-8.5 \%$ (-2.8\%) for $B / P(V / P$ insignificant) and the quintile difference for target CAR is $-4.3 \%(-2.6 \%)$. The $B / P$ findings are also consistent with the $Q$ hypothesis, since the value of bad targets can be improved the most and this gain can be shared with target shareholders.

Some consistent patterns emerge for bidding firms from Panels C and D. The probability of stock payment is strongly related to our misvaluation measures. Bidders that are more overvalued are more likely to use stock as consideration, consistent with Prediction 3.i and the prediction of Shleifer and Vishny (2003). The difference in probability of using stock between the top and bottom overvaluation quintiles is $14.8 \%(\mathrm{~V} / \mathrm{P})$ or $25.9 \%(B / P)$. An associated finding is that undervalued acquirers are more likely to use cash as consideration. The difference in the fraction of cash offers between the top and bottom misvaluation quintiles is $-5.6 \%(V / P)$ and $-14.1 \%(B / P)$. The $B / P$ findings are consistent with the 1978-1988 evidence of Martin (1996) and the 1980-1991 evidence of Rau and Vermaelen (1998), who find that, conditioning upon subsequent offer success, low bidder $B / P$ (or high $Q$ ) is associated with equity rather than cash or mixed offers.

There is some evidence that, consistent with Prediction 3.ii, overvalued acquirers pay higher bid premia, especially when the form of consideration is stock. Using the $B / P$ measure in Panel $\mathrm{C}$ the quintile difference in premium is $4.6 \%$ for the whole sample and (not reported in the table) $8.7 \%$ for stock acquisitions, significant differences. There is no significant effect for $V / P$ in Panel $\mathrm{D}$. The significant findings for $B / P$ suggest that overvalued bidders either find it easier to raise enough capital to make a high bid, and/or are more willing to make a high bid using an overvalue currency, their stock.

There is also some evidence, consistent with Prediction 3.iii, that offers by more overvalued bidders are associated with higher target stock returns. This effect is also much stronger among stock bids than in the entire sample. In Panel $\mathrm{C}$, the $B / P$ quintile difference in premium is $2.3 \%$ for the whole sample (significant at the $10 \%$ level), and (not reported in the table) $5.9 \%$ for stock acquisitions (highly significant). In contrast, the older samples of Lang, Stulz, and Walkling (1989) and Servaes (1991) indicated that (conditioning on subsequent offer success), there was no significant relation between bidder $Q$ and target return. In Panel D $V / P$ has essentially no effect; among stock offers (not reported in table) there is an economically substantial but statistically insignificant quintile difference of $3.0 \%$.

\footnotetext{
${ }^{29}$ In an early sample, Walkling and Edmister (1985) report that target $B / P$ is related to premium.
} 
Under the $Q$ hypothesis, high valuation bidders create greater total gains which are in part shared with targets. Thus, the findings that lower acquirer $B / P$ is associated with higher bid premia and target stock returns are also consistent with the $Q$ hypothesis. However, the $Q$ hypothesis does not predict that such effects are stronger in equity acquisitions.

Despite the indication that among stock offers, more overvalued bidders pay higher premia, there is no evidence that targets are more likely to view offers from overvalued bidders as friendly, nor that such offers have a greater probability of success. This is reasonable if target management understands that the bidder is overvalued. If so, then a higher premium in a stock offer is necessary merely to compensate for the fact that the market value of the offered shares is inflated relative to fundamental value.

Mean acquirer announcement period returns are significantly more negative when the acquirer is more overvalued based on both misvaluation measures. We call the strategy that is long on the top overvaluation quintile and short on the bottom overvaluation quintile the overvaluation-minus-undervaluation or OMU portfolio. The OMU portfolio abnormal return (describing the quintile difference in acquirer CARs) is $-1.6 \%(B / P)$ or $-1.9 \%(V / P)$. For $B / P$ the effect derives from the stock and merger subsamples; for $V / P$ the effect is strong with both stock and cash subsamples, and both merger and tender offer sub-samples (not reported in tables).

These substantial and highly significant return differentials are consistent with Prediction 4. This suggests that the announcement of a takeover bid tends to alert investors to preexisting mispricing, thereby causing a partial correction. This evidence is in sharp conflict with the $Q$ hypothesis, which predicts that a well-run bidder can generate greater gains from takeover.

As alluded to earlier, studies on earlier samples on Tobin's $Q$ variables (which tend to be inversely related to $B / P$ ) found very different results, that higher bidder valuation was associated with higher bidder returns. Our overall $B / P$ finding contrasts with the evidence, based on proxies for Tobin's $Q$ in a sample of successful mergers and tender offers from 1972-87 of Servaes (1991). Our finding within the tender offer subsample of no significant relation between acquirer $B / P$ ratios and announcement period acquirer returns (with a point estimate indicating low returns for bidders with low $B / P$ ) contrasts with the findings for successful tender offers of Lang, Stulz, and Walkling (1989) (from 1968-86); see also footnote 13.

Overall, as indicated in the Appendix Table, the univariate analysis offers strong support for the misvaluation hypothesis based on both $B / P$ and $V / P$ measures. The $Q$ 
hypothesis does not make predictions for $V / P$, and only a relatively few predictions for $B / P$. Several $B / P$ findings also tend to support the $Q$ hypothesis. However, where the two theories are directly opposed in their predictions (about the relation between bidder $B / P$ and bidder event-date returns), the results supports the misvaluation hypothesis and opposes the $Q$ hypothesis. The univariate evidence therefore supports the proposition that market misvaluation influences the behavior of both targets and bidders in takeover contests.

\section{Multivariate Tests}

To assess the robustness of our univariate findings, we perform multivariate analysis with additional controls described in Tables 4 and 5. Table 4 summarizes logistic regressions relating bidder and target misvaluation to the means of payment and to the mode and mood of the offer. The dependent variables we consider are: (1) cash payment, (2) stock payment, (3) tender offer, (4) hostility, and (5) success.

To ensure that our results concerning misvaluation do not result from low-frequency time-series swings, in the multivariate regressions in Tables 4 and 5, bidder and target $B / P$ and $V / P$ are ranked each month among all CRSP stocks and assigned a value between 1 and 100, somewhat along the lines of Frankel and Lee (1998). In all regressions we include size variables, leverage, year, and industry as controls. The industry controls are bidder 2-digit SIC major industry dummies as defined by Moskowitz and Grinblatt (1999).

We report three regression specifications for each dependent variable. First, we regress on bidder and target $B / P$ ranks. Second, we regress on bidder and target $V / P$. Third, we include both $B / P$ and $V / P$ ranks to examine whether there is incremental explanatory power from $V / P$ as a misvaluation measure given $B / P$. If so, this provides a fairly stringent confirmation that the identified effect is a result of misvaluation, rather than other economic factors possibly captured by book/market, such as risk premia, growth opportunities, or the degree of managerial discipline.

Our inclusion of leverage as a control distinguishes the misvaluation hypothesis from the financing constraint/debt capacity hypothesis. As in the preceding section, we only discuss the $Q$ hypothesis when it offers a prediction.

Consistent with Prediction 2.i, greater target overvaluation is associated with the use of stock as a means of payment (both $B / P$ and $V / P$ ). Similarly, the use of of 
cash is associated with target undervaluation $(B / P)$; the effect for target $V / P$ does not withstand inclusion of $B / P$ in the regression.

According to the misvaluation hypothesis, a target manager who understands that his firm is undervalued has an incentive to fight hard either to block the offer or to drive up the price. This in turn increases the incentive of the bidder to bypass management through a tender offer, as in Prediction 2.ii. Table 4 indicates that undervalued targets, as measured by $B / P$, do indeed have a significantly higher probability of opposing the offer (i.e. the frequency of hostile offers is higher). Furthermore, a similar relationship holds in a regression with target $V / P$ (significant at the $10 \%$ level). However, when both variables are included together, the $B / P$ remains whereas the incremental $V / P$ effect is close to zero. Thus, $V / P$ does not capture any misvaluation effect on hostility above and beyond that captured by $B / P$.

Table 4 also indicates that tender offers are significantly less likely (both $B / P$ and $V / P)$ when the measured overvaluation of targets is greater. This finding for $B / P$ is consistent with Prediction 2.iii of the misvaluation hypothesis.

Table 4 further indicates that target undervaluation, when measured by $B / P$ but not $V / P$, reduces the probability of offer success. Intuitively, bidders for undervalued targets have an incentive to try to get by with bids below true target value. This should provoke greater opposition by the target to the offer (consistent with the evidence discussed above), reducing the probability of success. The $B / P$ finding is consistent with Prediction 2.iv, but the lack of a $V / P$ effect does not support Prediction 2.iv.

Table 4 indicates that bidders with high measured overvaluation are more likely to pay with stock, and less likely to pay cash, consistent with Predictions 3.i of the misvaluation hypothesis and the prediction of Shleifer and Vishny (2003). ${ }^{30}$ The coefficients on acquirer $B / P$ in both the cash and stock regressions are significantly positive and negative respectively. ${ }^{31}$ Furthermore, the acquirer $V / P$ variables also have significant coefficients. The $V / P$ finding suggests that even in a test that stringently filters out growth-related effects, bidder overvaluation promotes the use of equity.

Greater bidder overvaluation (measured inversely by either $B / P$ or $V / P$ ) makes tender offers significantly less likely. The misvaluation hypothesis does not make a prediction in this regard, but a possible interpetation of this finding is that overvalued

\footnotetext{
${ }^{30}$ To make the regressions comparable, we impose the condition that data for both $B / P$ and $V / P$ be available. The results are generally similar if we expand the sample to include all firms for which data for $B / P$ are available in the regressions that do not involve $V / P$.

${ }^{31}$ The $B / P$ findings extend the evidence of Martin (1996) and Rau and Vermaelen (1998) about the relation of $B / P$ to the use of equity conditional upon subsequent offer success.
} 
bidders tend to use equity, which is rarely used in tender offers. There is little relation between estimated bidder overvaluation and either hostility or probability of success. Again, the misvaluation hypothesis is ambiguous with respect to this relation.

Table 5 examines whether misvaluation measures are related to bidder and target returns and the bid premium, after controlling for relative sizes of bidder and target, leverage, year, and industry as in Table 4. Consistent with Prediction 2.v, bid premia tend to be higher for targets that are more undervalued by both our measures. In contrast with the univariate results, the effect in the multivariate analysis is highly significant for $V / P$ as well as $B / P$. Intuitively, undervalued targets are prepared to fight harder for a high premium relative to market value. The $B / P$ effect is also consistent with the $Q$ hypothesis. However, the $V / P$ finding suggests that misvaluation is involved, rather than solely asset reallocation or agency effects.

In contrast with the univariate results, there is no significant relation between bidder announcement period returns and target overvaluation. This lack of an effect fails to support either Prediction 2.vi or the $Q$ hypothesis (or agency) prediction (see, e.g., Lang, Stulz, and Walkling (1989) and Servaes (1991), and Morck, Shleifer, and Vishny (1990)) that bidder gains are lower when acquiring well-run or rapidly-growing targets.

There is a weak negative relation between bidder $B / P$ and the bid premium. The confidence level is $p<.10$ when only $B / P$ is included in the regression, and is $p=.12$ when both $B / P$ and $V / P$ are included. This relation becomes significant at the $1 \%$ level within the stock offer subsample (in which the misvaluation effect should be strongest; not reported in tables). This evidence is generally consistent with Prediction 3.ii of the misvaluation hypothesis that more overvalued bidders offer higher premia. However, the results for $V / P$ are insignificant. The $B / P$ findings are also generally consistent with the $Q$ hypothesis, because bidders that generate high total gains share part of gains with their targets.

Prediction 3.iii of the misvaluation hypothesis is that overvalued bidders, by offering more, provide higher announcement returns to targets. In contrast with the somewhat mixed univariate evidence, the multivariate evidence fails to support this prediction. Bidder overvaluation is generally unrelated to target announcement period returns. The exception is that in the regression that contains $V / P$ but not $B / P$, acquirer $V / P$ has a positive effect that reaches significance at the $5 \%$ level, which opposes the prediction. The lack of a $B / P$ relation also fails to support the $Q$ hypothesis.

Bidder announcement period returns are greater for more undervalued bidders (for both $B / P$ and $V / P$ measures), consistent with Prediction 4 and directly opposed to the 
$B / P$ prediction of the $Q$ hypothesis. These findings contrast with evidence, discussed in Section 4, from older studies based on different time periods and somewhat different empirical measures; see also footnote 13. In a 1980-2001 sample of public acquisitions, Moeller, Schlingemann, and Stulz (2003a) find essentially no relation between Tobin's $\mathrm{Q}$ and the bidder's announcement period return. The differing conclusions may derive from their conditioning of returns on subsequent success of the offer, our longer sample period, or differences in control variables and in valuation proxies. ${ }^{32}$

As with the univariate evidence, these are highly significant effects. This evidence suggests that the act of takeover bidding tends to have a corrective effect on the misvaluation of the bidder. Apparently, investors tend to view an offer by an undervalued bidders as a masterful stroke, and an offer by an overvalued bidder as a clumsy blunder.

Overall, as indicated in the Appendix Table, the multivariate analysis generally further supports the misvaluation hypothesis based on both $B / P$ and $V / P$ measures. Since $B / P$ contains some incremental information about misvaluation, it is not surprising that overall the confirmation of the predicted findings for $V / P$ becomes a bit weaker. Nevertheless, a wide range of predictions of the misvaluation hypothesis are confirmed, and there is no significant finding in opposition. Several $B / P$ findings also support the $Q$ hypothesis. However, as with the univariate analysis, where the two theories directly disagree in their predictions (about the relation of bidder misvaluation to bidder returns), the results support the misvaluation hypothesis and oppose the $Q$ hypothesis. Overall, the multivariate evidence more strongly supports the proposition that market misvaluation influences the behavior of both targets and bidders in takeover contests.

\section{Summary and Conclusion}

We have examined the misvaluation hypothesis - that inefficient stock market misvaluation is an important driver of the takeover market - using contemporaneous measures of misvaluation of bidders and targets: book/price $(B / P)$, and the ratio of residual income valuation to price $(V / P)$. The $V / P$ variable allows us to determine whether a relation between market valuations and takeover characteristics is due to mispricing or to extraneous effects deriving from growth opportunities or the quality of bidder and target managements.

\footnotetext{
${ }^{32}$ Since bidders with low $B / P$ (documented here) and high $Q$ (Martin (1996)) tend to pay with equity, and since equity bidders for public firms tend to earn lower abnormal returns (Travlos (1987), Brown and Ryngaert (1991), Fuller, Netter, and Stegemoller (2002)), our finding is compatible with some other available evidence.
} 
Several empirical patterns emerge. With one or both measures, bidders are overvalued relative to their targets in both cash and equity offers, and in both mergers and tender offers. More overvalued bidders are more likely to use stock and less likely to use cash as consideration, are willing to pay more relative to target market price, are less inclined to use tender offer rather than merger bid, and earn lower announcement period returns. Undervalued targets receive higher premia relative to market price, are more likely to be hostile to the offer, are more likely to receive tender offers rather than merger bids, have a lower probability of being successfully acquired, and earn higher announcement period returns.

These findings are generally supportive of the misvaluation hypothesis. The $Q$ hypothesis offers a narrower range of predictions about bid premium and about bidder and target returns. The evidence provides mixed support for these predictions. In the case where the predictions of the two hypotheses are directly opposed, the findings support the misvaluation hypothesis. This evidence does not rule out the possibility of important growth/agency effects. However, taken as a whole, the evidence more strongly supports the proposition that inefficient mispricing of the stocks of targets and bidders influences their takeover-related decisions.

These findings raise the question of whether misvaluation drives aggregate patterns of takeover activity as well. Some recent papers examine aggregate valuation and the takeover market (Bouwman, Fuller, and Nain (2003), Dong, Hirshleifer, Richardson, and Teoh (2002), Verter (2003)). These papers confirm that there are long-term swings in market valuations and in aggregate takeover activity, and have offered some independent support for the misvaluation hypothesis. A challenge for this literature is that the effective sample size is reduced by the low frequency of merger waves. Furthermore, aggregate misvaluation measures mix the effects of bidder and target mispricing. The cross-sectional tests we offer here filter away any effects of aggregate valuations, and disentangle the effects of bidder versus target misvaluation. Our tests are therefore complementary with those of these papers.

There is no reason to believe that the influence of market misvaluation on managerial decisions is limited to the takeover market. As discussed earlier, previous research has provided evidence that financing, repurchase, reporting, and investment decisions are related to misvaluation. Thus, our evidence contributes to an emerging theme in recent literature that misvaluation is likely to be important for many of the decisions that firms make.

This body of evidence presents a challenge to the traditional theory of corporate 
finance, which is premised upon the efficient markets hypothesis. There have been some initial steps toward incorporating misvaluation into the theory of takeover transactions (see Shleifer and Vishny (2003)), financing, and investment decisions (see Stein (1996) and Daniel, Hirshleifer, and Subrahmanyam (1998)). The emerging indications that misvaluation has important effects suggest that further theoretical analysis of how firms can exploit misvaluation may be fruitful. 


\section{References}

Ali, A., L.-S. Hwang, and M. A. Trombley, 2003, Residual-income-based valuation predicts future stock returns: Evidence on mispricing versus risk explanations, Accounting Review 78, 377-396.

Andrade, G., M. L. Mitchell, and E. Stafford, 2001, New evidence and perspectives on mergers, Journal of Economic Perspectives 15, 103-120.

Ang, J. S. and Y. Cheng, 2003, Direct evidence on the market-driven acquisitions theory, Working Paper, Florida State University.

Baker, M. and J. Wurgler, 2000, The equity share in new issues and aggregate stock returns, Journal of Finance 55, 2219-2257.

Baker, M. P., J. C. Stein, and J. Wurgler, 2003, When does the market matter? stock prices and the investment of equity-dependent firms, Quarterly Journal of Economics 118, 969-1005.

Baker, M. P. and J. Wurgler, 2002, Market timing and capital structure, Journal of Finance 57, 1-32.

Barber, B. M. and J. D. Lyon, 1997, Detecting long-run abnormal stock returns: The empirical power and specification of test statistics, Journal of Financial Economics 43, 341-372.

Barberis, N. and M. Huang, 2001, Mental accounting, loss aversion, and individual stock returns, Journal of Finance 56, 1247-1292.

Bouwman, C., K. Fuller, and A. Nain, 2003, The performance of stock-price driven acquisitions: An empirical examination, Working Paper, University of Michigan Business School.

Brealey, R. A. and S. C. Myers, 2000, Principles of corporate finance (6th ed.). (McGraw-Hill, New York).

Brown, D. T. and M. D. Ryngaert, 1991, The mode of acquisition in takeovers: Taxes and asymmetric information, Journal of Finance 46, 653-669.

Chemmanur, T. and I. Paeglis, 2002, The choice of the medium of exchange in acquisitions: A direct test of the double-sided asymmetric information hypothesis, Boston College, Unpublished manuscript.

Cohen, R. B., C. K. Polk, and T. Vuolteenaho, 2002, Does risk or mispricing explain the cross-section of stock prices?, Harvard Business School Working Paper Series, No. 03-107.

Daniel, K. D., D. Hirshleifer, and A. Subrahmanyam, 1998, Investor psychology and security market under- and over-reactions, Journal of Finance 53, 1839-1886.

Daniel, K. D., D. Hirshleifer, and A. Subrahmanyam, 2001, Overconfidence, arbitrage, and equilibrium asset pricing, Journal of Finance 56, 921-965. 
Daniel, K. D., D. Hirshleifer, and S. H. Teoh, 2002, Investor psychology in capital markets: Evidence and policy implications, Journal of Monetary Economics 49 (1)/Carnegie Rochester Series in Public Policy 56, 139-209.

Daniel, K. D. and S. Titman, 1997, Evidence on the characteristics of cross-sectional variation in common stock returns, Journal of Finance 52, 1-33.

D'Mello, R. and P. K. Shrof, 2000, Equity undervaluation and decisions related to repurchase tender offers: An empirical investigation, Journal of Finance 55, 2399 -2424 .

Dong, M., D. Hirshleifer, S. Richardson, and S. H. Teoh, 2002, Does investor misvaluation drive the takeover market?, Working paper, Ohio State University, York University and Wharton School.

Fama, E. F., 1998, Market efficiency, long-term returns and behavioral finance, Journal of Financial Economics 49, 283-306.

Fama, E. F. and K. R. French, 1996, Multifactor explanations of asset pricing anomalies, Journal of Finance 51, 55-84.

Frankel, R. and C. Lee, 1998, Accounting valuation, market expectation, and the book-to-market effect, Journal of Accounting and Economics 25, 283-321.

Franks, J., R. Harris, and S. Titman, 1991, The postmerger share-price performance of acquiring firms, Journal of Financial Economics 29, 81-96.

Fuller, K., J. Netter, and M. Stegemoller, 2002, What do returns to acquiring firms tell us? evidence from firms that make many acquisitions, Journal of Finance 57, 1763-1793.

Gort, M., 1969, An economic disturbance theory of mergers, The Quarterly Journal of Economics 83, 624-642.

Griffin, J. M. and M. L. Lemmon, 2002, Book-to-market equity, distress risk, and stock returns, Journal of Finance 57, 2317-2336.

Hirshleifer, D., 2001, Investor psychology and asset pricing, Journal of Finance 64, 1533-1597.

Holmstrom, B. R. and S. N. Kaplan, 2001, Corporate governance and merger activity in the U.S.: Making sense of the 1980s and 1990s, MIT Dept. of Economics Working Paper No. 01-11.

Jensen, M. C., 1986, Agency costs of free cash flow, corporate finance, and takeovers, American Economic Review 76, 323-329.

Jovanovic, B. and P. L. Rousseau, 2002, The Q-theory of mergers, American Economic Review 92, 198-204.

Lang, L. H. P., R. Stulz, and R. A. Walkling, 1989, Managerial performance, Tobin's q, and the gains from successful tender offers, Journal of Financial Economics 24, $137-154$.

Lee, C. M., J. Myers, and B. Swaminathan, 1999, What is the intrinsic value of the Dow?, Journal of Finance 54, 1693-1741. 
Loughran, T. and J. Ritter, 1995, The new issues puzzle, Journal of Finance 50, $23-52$.

Loughran, T. and J. Ritter, 2000, Uniformly least powerful tests of market efficiency, Journal of Financial Economics 55, 361-389.

Loughran, T. and A. M. Vijh, 1997, Do long-term shareholders benefit from corporate acquisitions?, Journal of Finance 52, 1765-1790.

Martin, K. J., 1996, The method of payment in corporate acquisitions, investment opportunities, and management ownership, Journal of Finance 51, 1227-1246.

Mitchell, M. and E. Stafford, 2000, Managerial decisions and long-term stock price performance, Journal of Business 73, 287-320.

Moeller, S. B., F. P. Schlingemann, and R. Stulz, 2003, Do shareholders of acquiring firms gain from acquisitions?, The Ohio State University, Dice Center Working Paper Series 2003-4.

Moeller, S. B., F. P. Schlingemann, and R. M. Stulz, 2003, Wealth destruction on a massive scale? A study of acquiring-firm returns in the merger wave of the late 1990s, Working Paper, The Ohio State University.

Morck, R., A. Shleifer, and R. W. Vishny, 1990, Do managerial objectives drive bad acquisitions?, Journal of Finance 45, 31-48.

Moskowitz, T. J. and M. Grinblatt, 1999, Do industries explain momentum?, Journal of Finance 54, 1249-1290.

Ohlson, J., 1995, Earnings, book values, and dividends in equity valuation, Contemporary Accounting Research 11, 661-687.

Polk, C. and P. Sapienza, 2003, The real effects of investor sentiment, working paper, Kellogg School of Management, Northwestern University.

Rajan, R. G. and H. Servaes, 1997, Analyst following of initial public offerings, Journal of Finance 52, 507-530.

Rau, P. R. and T. Vermaelen, 1998, Glamour, value and the post-acquisition performance of acquiring firms, Journal of Financial Economics 49, 223-253.

Rhodes-Kropf, M., D. T. Robinson, and S. Viswanathan, 2003, Valuation waves and merger activity: The empirical evidence, Working Paper, Columbia University and Duke University.

Ritter, J. R., 1991, The long-run performance of initial public offerings, Journal of Finance 46, 3-27.

Schwert, G., 2000, Hostility in takeovers: In the eyes of the beholder?, Journal of Finance 55, 2599-2640.

Servaes, H., 1991, Tobin's Q and the gains from takeovers, Journal of Finance 46, 409-419.

Shleifer, A. and R. W. Vishny, 2003, Stock market driven acquisitions, Forthcoming, Journal of Financial Economics. 
Stein, J., 1996, Rational capital budgeting in an irrational world, Journal of Business 69, 429-455.

Teoh, S. H., I. Welch, and T. J. Wong, 1998, Earnings management and the long-term market performance of initial public offerings, Journal of Finance 53, 1935-1974.

Teoh, S. H., I. Welch, and T. J. Wong, 1998, Earnings management and the underperformance of seasoned equity offerings, Journal of Financial Economics 50, 63-99.

Teoh, S. H., T. J. Wong, and G. Rao, 1998, Are accruals during an initial public offering opportunistic?, Review of Accounting Studies 3, 175-208.

Travlos, N. G., 1987, Corporate takeover bids, methods of payment, and bidding firm's stock returns, Journal of Finance 42, 943-963.

Vassalou, M. and Y. Xing, 2003, Default risk in equity returns, Forthcoming, Journal of Finance.

Verter, G., 2003, Timing merger waves, Harvard University.

Walkling, R. A. and R. O. Edmister, 1985, Determinants of tender offer premiums, Financial Analysts Journal 41, 27-37. 
Table 1

Descriptive Statistics for Takeover Bids

Number of takeover bids, mean value of transaction, and percentage of transactions that are successful, hostile, tender offers, merger bids, all cash payment, all stock payment, and mixed payment, by calendar year. Sample includes merger bids and tender offers where both acquirer and target were listed on the NYSE, AMEX, or NASDAQ during 1978-2000. All dollar figures are in millions of 2001 dollars.

\begin{tabular}{cccccccccc}
\hline Year & N & $\begin{array}{c}\text { Mean value } \\
\text { per } \\
\text { transaction }\end{array}$ & $\begin{array}{c}\text { \% } \\
\text { successful }\end{array}$ & $\begin{array}{c}\text { \% } \\
\text { hostile }\end{array}$ & $\begin{array}{c}\text { \% } \\
\text { tender } \\
\text { offers }\end{array}$ & $\begin{array}{c}\text { \% } \\
\text { merger } \\
\text { bids }\end{array}$ & $\begin{array}{c}\text { \% } \\
\text { cash }\end{array}$ & $\begin{array}{c}\text { \% } \\
\text { stock }\end{array}$ & $\begin{array}{c}\text { \% } \\
\text { mixed }\end{array}$ \\
\hline 1978 & 17 & 1046.7 & 76.5 & 23.5 & 29.4 & 70.6 & 52.9 & 47.1 & 0.0 \\
1979 & 11 & 981.1 & 63.6 & 10.0 & 27.3 & 72.7 & 90.9 & 9.1 & 0.0 \\
1980 & 29 & 872.5 & 75.9 & 11.5 & 24.1 & 75.9 & 20.7 & 3.4 & 75.9 \\
1981 & 99 & 1509.1 & 60.6 & 13.1 & 23.2 & 76.8 & 6.1 & 0.0 & 93.9 \\
1982 & 89 & 624.3 & 68.5 & 18.0 & 28.1 & 71.9 & 0.0 & 0.0 & 100.0 \\
1983 & 105 & 644.0 & 70.5 & 11.7 & 20.0 & 80.0 & 4.8 & 0.0 & 95.2 \\
1984 & 120 & 840.2 & 61.7 & 11.0 & 31.7 & 68.3 & 17.5 & 5.8 & 76.7 \\
1985 & 157 & 1031.5 & 67.5 & 15.3 & 33.1 & 66.9 & 45.9 & 31.2 & 22.9 \\
1986 & 139 & 813.5 & 67.6 & 15.4 & 31.7 & 68.3 & 52.5 & 26.6 & 20.9 \\
1987 & 167 & 695.5 & 66.5 & 13.4 & 21.0 & 79.0 & 40.1 & 28.1 & 31.7 \\
1988 & 161 & 630.2 & 55.3 & 15.2 & 35.4 & 64.6 & 61.5 & 21.7 & 16.8 \\
1989 & 128 & 972.0 & 64.1 & 13.4 & 30.5 & 69.5 & 39.8 & 38.3 & 21.9 \\
1990 & 74 & 710.5 & 73.0 & 7.6 & 16.2 & 83.8 & 35.1 & 37.8 & 27.0 \\
1991 & 85 & 491.4 & 78.8 & 3.7 & 10.6 & 89.4 & 10.6 & 61.2 & 28.2 \\
1992 & 97 & 423.3 & 81.4 & 3.1 & 5.2 & 94.8 & 16.5 & 62.9 & 20.6 \\
1993 & 120 & 1101.6 & 85.8 & 2.6 & 10.8 & 89.2 & 26.7 & 47.5 & 25.8 \\
1994 & 206 & 585.2 & 80.6 & 7.3 & 14.6 & 85.4 & 29.6 & 54.9 & 15.5 \\
1995 & 248 & 827.4 & 84.3 & 7.3 & 14.1 & 85.9 & 25.0 & 58.9 & 16.1 \\
1996 & 264 & 1126.1 & 84.8 & 7.2 & 14.4 & 85.6 & 23.9 & 50.4 & 25.8 \\
1997 & 366 & 1197.6 & 87.7 & 4.2 & 16.4 & 83.6 & 16.4 & 54.9 & 28.7 \\
1998 & 342 & 2982.8 & 89.5 & 2.4 & 12.9 & 87.1 & 16.1 & 57.3 & 26.6 \\
1999 & 394 & 3064.5 & 84.0 & 3.9 & 17.0 & 83.0 & 24.1 & 46.2 & 29.7 \\
2000 & 314 & 2951.1 & 85.7 & 2.3 & 20.1 & 79.9 & 25.5 & 48.1 & 26.4 \\
Total & 3732 & 1481.1 & 78.3 & 7.6 & 19.4 & 80.6 & 26.2 & 41.6 & 32.2 \\
\hline & & & & & & & & &
\end{tabular}


Table 2

Mean Acquirer and Target Valuation Ratios by Mode of the Offer and Payment Method

The valuation ratios are the book-price ratio $\mathrm{B} / \mathrm{P}$ and the intrinsic value-price ratio V/P. The intrinsic value is estimated using the residual income model (RIM) when the discount rate is based on firm-specific CAPM. T-statistic of differences between acquirer and target, and between cash and stock offers are reported in parentheses. For each valuation ratio, we require that both the acquirer and the target have non-missing values. Sample includes both successful and unsuccessful merger bids and tender offers where both acquirer and target were listed on the NYSE, AMEX, or NASDAQ during 1978-2000.

\begin{tabular}{|c|c|c|c|c|c|c|c|c|c|c|c|c|c|}
\hline & \multirow[b]{2}{*}{ Ratio } & \multicolumn{4}{|c|}{ Tender Offers } & \multicolumn{4}{|c|}{ Merger Bids } & \multicolumn{4}{|c|}{ All } \\
\hline & & Acquirer & Target & $\begin{array}{c}\text { Acquirer } \\
- \text { Target } \\
\text { (t-stat) }\end{array}$ & $\mathrm{N}$ & Acquirer & Target & $\begin{array}{c}\text { Acquirer } \\
- \text { Target } \\
\text { (t-stat) }\end{array}$ & $\mathrm{N}$ & Acquirer & Target & $\begin{array}{c}\text { Acquirer } \\
\text { - Target } \\
\text { (t-stat) }\end{array}$ & $\mathrm{N}$ \\
\hline \multirow[t]{2}{*}{ Cash } & $\mathrm{B} / \mathrm{P}$ & 0.589 & 0.742 & $\begin{array}{l}-0.153 \\
(-3.68)\end{array}$ & 379 & 0.727 & 0.799 & $\begin{array}{l}-0.072 \\
(-1.97)\end{array}$ & 387 & 0.659 & 0.771 & $\begin{array}{l}-0.112 \\
(-4.05)\end{array}$ & 766 \\
\hline & $\mathrm{V} / \mathrm{P}$ & 0.764 & 0.815 & $\begin{array}{l}-0.051 \\
(-1.49)\end{array}$ & 214 & 0.792 & 0.859 & $\begin{array}{l}-0.068 \\
(-1.57)\end{array}$ & 148 & 0.775 & 0.833 & $\begin{array}{l}-0.058 \\
(-2.15)\end{array}$ & 362 \\
\hline \multirow[t]{2}{*}{ Stock } & $\mathrm{B} / \mathrm{P}$ & 0.591 & 0.755 & $\begin{array}{l}-0.164 \\
(-1.26)\end{array}$ & 19 & 0.409 & 0.549 & $\begin{array}{c}-0.140 \\
(-12.09)\end{array}$ & 1227 & 0.412 & 0.552 & $\begin{array}{c}-0.140 \\
(-12.14)\end{array}$ & 1246 \\
\hline & $\mathrm{V} / \mathrm{P}$ & 0.682 & 0.660 & $\begin{array}{l}0.022 \\
(0.26)\end{array}$ & 17 & 0.6423 & 0.758 & $\begin{array}{l}-0.125 \\
(-7.50)\end{array}$ & 736 & 0.634 & 0.756 & $\begin{array}{l}-0.122 \\
(-7.41)\end{array}$ & 753 \\
\hline \multirow[t]{2}{*}{ Mixed } & $\mathrm{B} / \mathrm{P}$ & 0.821 & 0.862 & $\begin{array}{l}-0.040 \\
(-0.74)\end{array}$ & 210 & 0.722 & 0.747 & $\begin{array}{l}-0.025 \\
(-0.29)\end{array}$ & 694 & 0.745 & 0.774 & $\begin{array}{l}-0.028 \\
(-0.42)\end{array}$ & 904 \\
\hline & $\mathrm{V} / \mathrm{P}$ & 0.800 & 0.757 & $\begin{array}{l}0.043 \\
(0.89)\end{array}$ & 90 & 0.757 & 0.827 & $\begin{array}{l}-0.070 \\
(-2.45)\end{array}$ & 342 & 0.766 & 0.813 & $\begin{array}{l}-0.047 \\
(-1.87)\end{array}$ & 432 \\
\hline \multirow[t]{3}{*}{ All } & $\mathrm{B} / \mathrm{P}$ & 0.669 & 0.784 & $\begin{array}{l}-0.114 \\
(-3.55)\end{array}$ & 608 & 0.556 & 0.650 & $\begin{array}{l}-0.094 \\
(-3.46)\end{array}$ & 2308 & 0.580 & 0.678 & $\begin{array}{l}-0.098 \\
(-4.35)\end{array}$ & 2916 \\
\hline & $\mathrm{V} / \mathrm{P}$ & 0.770 & 0.791 & $\begin{array}{l}-0.021 \\
(-0.77)\end{array}$ & 321 & 0.686 & 0.790 & $\begin{array}{l}-0.103 \\
(-7.43)\end{array}$ & 1226 & 0.704 & 0.790 & $\begin{array}{l}-0.086 \\
(-6.95)\end{array}$ & 1547 \\
\hline & & Acquirer & Target & & & Acquirer & Target & & & Acquirer & Target & & \\
\hline $\begin{array}{c}\text { Cash - Stock } \\
(\text { t-stat })\end{array}$ & $\mathrm{B} / \mathrm{P}$ & $\begin{array}{l}-0.001 \\
(-0.01)\end{array}$ & $\begin{array}{l}-0.013 \\
(-0.10)\end{array}$ & & & $\begin{array}{c}0.318 \\
(11.19)\end{array}$ & $\begin{array}{l}0.250 \\
(7.94)\end{array}$ & & & $\begin{array}{c}0.247 \\
(11.75)\end{array}$ & $\begin{array}{l}0.219 \\
(8.10)\end{array}$ & & \\
\hline $\begin{array}{c}\text { Cash - Stock } \\
\text { (t-stat) }\end{array}$ & $\mathrm{V} / \mathrm{P}$ & $\begin{array}{l}0.082 \\
(1.29)\end{array}$ & $\begin{array}{l}0.155 \\
(1.91)\end{array}$ & & & $\begin{array}{l}0.159 \\
(4.73)\end{array}$ & $\begin{array}{l}0.102 \\
(2.33)\end{array}$ & & & $\begin{array}{l}0.142 \\
(6.07)\end{array}$ & $\begin{array}{l}0.078 \\
(2.55)\end{array}$ & & \\
\hline
\end{tabular}


Table 3

\section{Mean Acquisition Characteristics by Acquirer or Target Valuation Ratio Quintiles}

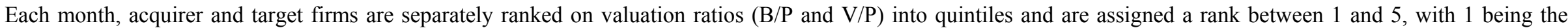

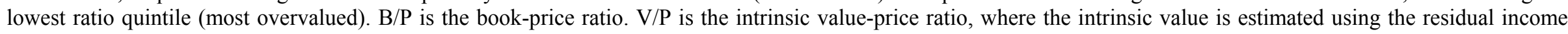

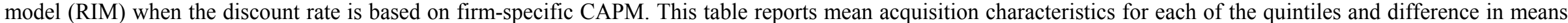

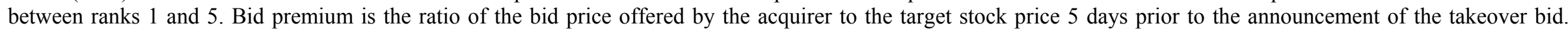

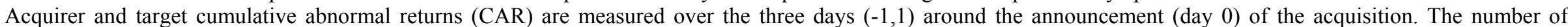

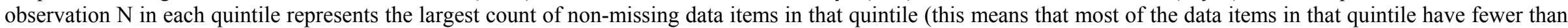

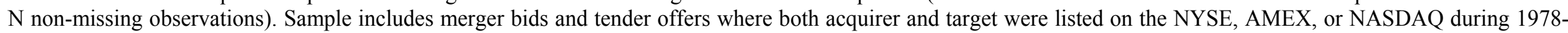
2000.

$* * *, * *, *$ denote difference in means between ranks 1 and 5 is significant at the $1 \%, 5 \%, 10 \%$ level, respectively, based on the two-sample t-test.

\begin{tabular}{|c|c|c|c|c|c|c|c|c|c|c|}
\hline & & & $\begin{array}{l}\text { Probability } \\
\text { of cash } \\
\text { payment } \\
(\%)\end{array}$ & $\begin{array}{c}\text { Probability } \\
\text { of stock } \\
\text { payment } \\
(\%)\end{array}$ & $\begin{array}{l}\text { Probability } \\
\text { of tender } \\
\text { offer } \\
(\%)\end{array}$ & $\begin{array}{l}\text { Probability } \\
\text { of hostile } \\
\text { acquisition } \\
(\%)\end{array}$ & $\begin{array}{l}\text { Probability } \\
\text { of } \\
\text { successful } \\
\text { acquisition } \\
(\%) \\
\end{array}$ & $\begin{array}{l}\text { Bid } \\
\text { premium } \\
(\%)\end{array}$ & $\begin{array}{c}\text { Target } \\
\text { announce- } \\
\text { ment CAR } \\
(\%)\end{array}$ & $\begin{array}{c}\text { Acquirer } \\
\text { announce- } \\
\text { ment CAR } \\
(\%)\end{array}$ \\
\hline \multicolumn{11}{|c|}{ Panel A. Acquisitions sorted monthly by target $\mathrm{B} / \mathrm{P}$ ratio } \\
\hline $\begin{array}{c}\text { Target } \\
\text { B/P Rank }\end{array}$ & $\mathrm{N}$ & $\begin{array}{c}\text { Target } \\
\mathrm{B} / \mathrm{P}\end{array}$ & & & & & & & & \\
\hline 1 & 518 & 0.148 & 18.3 & 53.9 & 14.7 & 4.1 & 83.0 & 29.9 & 15.9 & -1.6 \\
\hline 2 & 680 & 0.400 & 24.4 & 48.5 & 22.1 & 6.4 & 79.9 & 32.4 & 17.3 & -2.0 \\
\hline 3 & 691 & 0.608 & 28.7 & 40.8 & 23.2 & 7.0 & 81.2 & 32.7 & 17.8 & -1.2 \\
\hline 4 & 678 & 0.862 & 27.6 & 37.2 & 21.5 & 10.6 & 77.4 & 35.0 & 19.0 & -1.2 \\
\hline 5 & 570 & 1.388 & 30.7 & 31.2 & 23.0 & 12.0 & 73.7 & 38.4 & 20.1 & -0.3 \\
\hline Difference 1-5 & & $-1.240 * * *$ & $-12.4 * * *$ & $22.6^{* * *}$ & $-8.3 * * *$ & $-7.9 * * *$ & $9.3^{* * *}$ & $-8.5 * * *$ & $-4.3 * * *$ & $-1.4 * * *$ \\
\hline
\end{tabular}

Panel B. Acquisitions sorted monthly by target $\mathrm{V} / \mathrm{P}$ ratio

\begin{tabular}{|c|c|c|c|c|c|c|c|c|c|c|}
\hline $\begin{array}{c}\text { Target } \\
\text { V/P Rank } \\
\end{array}$ & $\mathrm{N}$ & $\begin{array}{c}\text { Target } \\
\text { V/P } \\
\end{array}$ & & & & & & & & \\
\hline 1 & 284 & 0.305 & 20.8 & 59.2 & 16.2 & 4.7 & 85.6 & 33.1 & 17.1 & -2.7 \\
\hline 2 & 436 & 0.506 & 22.2 & 48.4 & 21.1 & 8.5 & 80.3 & 33.1 & 17.8 & -2.3 \\
\hline 3 & 431 & 0.707 & 27.8 & 43.4 & 26.0 & 10.7 & 78.2 & 33.8 & 18.9 & -1.7 \\
\hline 4 & 436 & 0.965 & 24.3 & 40.8 & 22.9 & 11.0 & 77.5 & 35.3 & 19.9 & -1.2 \\
\hline 5 & 318 & 1.447 & 27.0 & 41.5 & 23.6 & 10.3 & 79.6 & 35.9 & 19.7 & -1.0 \\
\hline Difference 1-5 & & $-1.141 * * *$ & $-6.3 *$ & $17.6 * * *$ & $-7.4 * *$ & $-5.6 * * *$ & $6.0 *$ & -2.8 & -2.6 & $-1.8 * * *$ \\
\hline
\end{tabular}


Table 3 (contd.)

Mean Acquisition Characteristics by Acquirer or Target Valuation Ratio Quintiles

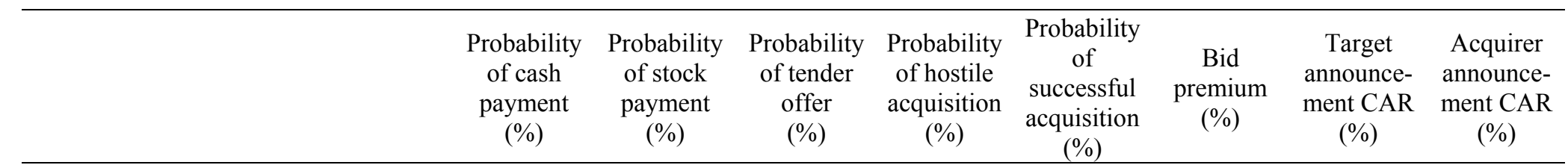

Panel C. Acquisitions sorted monthly by acquirer $B / P$ ratio

\begin{tabular}{|c|c|c|c|c|c|c|c|c|c|c|}
\hline $\begin{array}{l}\text { Acquirer } \\
\text { B/P Rank }\end{array}$ & $\mathrm{N}$ & $\begin{array}{c}\text { Acquirer } \\
\mathrm{B} / \mathrm{P}\end{array}$ & & & & & & & & \\
\hline 1 & 575 & 0.140 & 19.3 & 54.1 & 15.1 & 6.6 & 81.4 & 36.4 & 19.0 & -2.0 \\
\hline 2 & 734 & 0.348 & 23.8 & 46.2 & 19.5 & 5.9 & 81.1 & 35.5 & 19.7 & -1.4 \\
\hline 3 & 729 & 0.524 & 25.4 & 44.4 & 19.5 & 7.4 & 78.6 & 35.0 & 17.9 & -1.6 \\
\hline 4 & 736 & 0.725 & 27.6 & 39.9 & 21.1 & 8.8 & 78.3 & 32.8 & 17.0 & -0.9 \\
\hline 5 & 628 & 1.302 & 33.4 & 28.2 & 22.0 & 8.8 & 78.0 & 31.8 & 16.8 & -0.4 \\
\hline Difference 1-5 & & $-1.162 * * *$ & $-14.1 * * *$ & $25.9 * * *$ & $-6.8 * * *$ & -2.2 & 3.4 & $4.6^{* * *}$ & $2.3^{*}$ & $-1.6 * * *$ \\
\hline
\end{tabular}

Panel D. Acquisitions sorted monthly by acquirer V/P ratio

\begin{tabular}{|c|c|c|c|c|c|c|c|c|c|c|}
\hline $\begin{array}{l}\text { Acquirer } \\
\text { V/P Rank }\end{array}$ & $\mathrm{N}$ & $\begin{array}{c}\text { Acquirer } \\
\text { V/P }\end{array}$ & & & & & & & & \\
\hline 1 & 428 & 0.321 & 20.1 & 55.8 & 13.6 & 5.5 & 79.9 & 35.9 & 18.2 & -2.7 \\
\hline 2 & 591 & 0.523 & 28.4 & 43.3 & 20.5 & 6.0 & 81.9 & 34.5 & 20.5 & -1.5 \\
\hline 3 & 584 & 0.718 & 27.6 & 42.6 & 23.5 & 8.5 & 79.6 & 35.1 & 20.2 & -1.2 \\
\hline 4 & 589 & 0.924 & 26.5 & 42.4 & 18.8 & 5.6 & 85.4 & 33.8 & 18.1 & -1.2 \\
\hline 5 & 483 & 1.318 & 25.7 & 41.0 & 18.2 & 7.8 & 78.9 & 36.0 & 18.6 & -0.8 \\
\hline Difference 1-5 & & $-0.997 * * *$ & $-5.6 * *$ & $14.8 * * *$ & $-4.7 * *$ & -2.4 & 1.0 & -0.1 & -0.4 & $-1.9 * * *$ \\
\hline
\end{tabular}


Table 4

Logistic Regressions

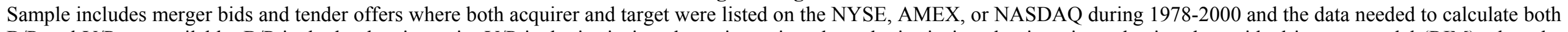

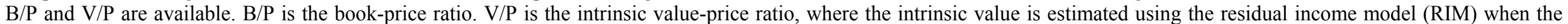

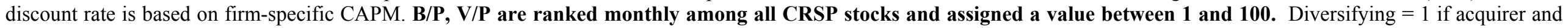

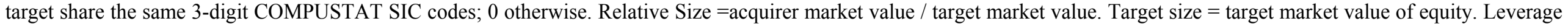

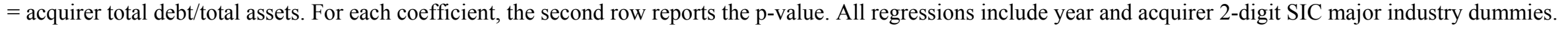

\begin{tabular}{|c|c|c|c|c|c|c|c|c|c|c|c|c|c|c|c|}
\hline \multirow{4}{*}{ Target $\mathbf{B} / \mathbf{P}$} & \multicolumn{15}{|c|}{ Dependent Variable (=1 if yes, 0 otherwise) } \\
\hline & \multicolumn{3}{|c|}{ Cash } & \multicolumn{3}{|c|}{ Stock } & \multicolumn{3}{|c|}{ Tender Offer } & \multicolumn{3}{|c|}{ Hostile } & \multicolumn{3}{|c|}{ Success } \\
\hline & 0.009 & & 0.007 & -0.020 & & -0.018 & 0.014 & & 0.012 & 0.021 & & 0.021 & -0.017 & & -0.017 \\
\hline & 0.011 & & 0.041 & 0.000 & & 0.000 & 0.000 & & 0.002 & 0.000 & & 0.000 & 0.000 & & 0.000 \\
\hline \multirow[t]{2}{*}{ Acquirer B/P } & 0.025 & & 0.021 & -0.028 & & -0.024 & 0.021 & & 0.016 & 0.000 & & 0.001 & 0.006 & & 0.006 \\
\hline & 0.000 & & 0.000 & 0.000 & & 0.000 & 0.000 & & 0.000 & 0.975 & & 0.934 & 0.124 & & 0.178 \\
\hline \multirow[t]{2}{*}{ Target V/P } & & 0.005 & 0.003 & & -0.007 & -0.005 & & 0.007 & 0.005 & & 0.008 & 0.006 & & -0.002 & 0.000 \\
\hline & & 0.094 & 0.239 & & 0.003 & 0.047 & & 0.026 & 0.077 & & 0.094 & 0.223 & & 0.550 & 0.967 \\
\hline \multirow[t]{2}{*}{ Acquirer V/P } & & 0.017 & 0.009 & & -0.019 & -0.008 & & 0.019 & 0.013 & & 0.001 & -0.003 & & -0.001 & 0.001 \\
\hline & & 0.000 & 0.008 & & 0.000 & 0.008 & & 0.000 & 0.000 & & 0.825 & 0.583 & & 0.844 & 0.731 \\
\hline \multirow[t]{2}{*}{ Diversifying } & 0.361 & 0.386 & 0.372 & -0.461 & -0.470 & -0.478 & 0.526 & 0.538 & 0.549 & 0.739 & 0.771 & 0.756 & -0.262 & -0.249 & -0.260 \\
\hline & 0.030 & 0.020 & 0.026 & 0.002 & 0.001 & 0.001 & 0.003 & 0.003 & 0.003 & 0.005 & 0.003 & 0.004 & 0.140 & 0.159 & 0.144 \\
\hline $\log$ of & 0.417 & 0.339 & 0.443 & -0.220 & -0.119 & -0.240 & 0.216 & 0.154 & 0.247 & -0.523 & -0.552 & -0.512 & 0.448 & 0.447 & 0.449 \\
\hline Relative Size & 0.000 & 0.000 & 0.000 & 0.000 & 0.011 & 0.000 & 0.000 & 0.005 & 0.000 & 0.000 & 0.000 & 0.000 & 0.000 & 0.000 & 0.000 \\
\hline Log of Target & 0.062 & 0.000 & 0.083 & -0.173 & -0.062 & -0.197 & 0.192 & 0.126 & 0.223 & 0.368 & 0.304 & 0.386 & -0.148 & -0.101 & -0.148 \\
\hline Size & 0.302 & 0.998 & 0.177 & 0.001 & 0.197 & 0.000 & 0.002 & 0.032 & 0.000 & 0.000 & 0.000 & 0.000 & 0.013 & 0.085 & 0.014 \\
\hline \multirow[t]{2}{*}{ Leverage } & -0.691 & -0.407 & -0.785 & -0.894 & -1.346 & -0.880 & -0.868 & -0.630 & -1.076 & 0.208 & 0.694 & 0.202 & 0.634 & 0.373 & 0.631 \\
\hline & 0.222 & 0.459 & 0.172 & 0.058 & 0.003 & 0.064 & 0.129 & 0.264 & 0.068 & 0.798 & 0.379 & 0.805 & 0.261 & 0.499 & 0.263 \\
\hline \multirow[t]{2}{*}{ Intercept } & -4.041 & -3.023 & -4.498 & 3.744 & 2.011 & 4.213 & -4.074 & -3.124 & -4.717 & -6.513 & -5.609 & -6.838 & 2.828 & 2.084 & 2.817 \\
\hline & 0.000 & 0.000 & 0.000 & 0.000 & 0.000 & 0.000 & 0.000 & 0.000 & 0.000 & 0.000 & 0.000 & 0.000 & 0.000 & 0.002 & 0.000 \\
\hline Sample Size & 1513 & 1513 & 1513 & 1513 & 1513 & 1513 & 1513 & 1513 & 1513 & 1479 & 1479 & 1479 & 1513 & 1513 & 1513 \\
\hline Pseudo-R ${ }^{2}$ & .1790 & .1634 & .1850 & .2232 & .1860 & .2302 & .1915 & .1851 & .2044 & .2238 & .2084 & .2256 & .1359 & .1227 & .1359 \\
\hline
\end{tabular}


Table 5

Least Squares Regressions

Acquirer and target announcement period cumulative abnormal returns (CAR) are measured over the three days $(-1,1)$ around the announcement (day 0$)$ of the acquisition. Bid premium is the ratio of the bid price offered by the acquirer to the target stock price 5 days prior to the announcement of the takeover bid. Sample includes merger bids and tender offers where both acquirer and target were listed on the NYSE, AMEX, or NASDAQ during 1978-2000 and the data needed to calculate both B/P and V/P are available. B/P is the book-price ratio. V/P is the intrinsic value-price ratio, where the intrinsic value is estimated using the residual income model (RIM) when the discount rate is based on firm-specific CAPM. B/P, V/P are ranked monthly among all CRSP stocks and assigned a value between 1 and 100. Relative Size $=$ acquirer market value $/$ target market value. Target size $=$ target market value of equity. Leverage $=$ acquirer total debt/total assets. For each coefficient, the second row reports the t-statistic. All regressions include year and acquirer 2-digit SIC major industry dummies.

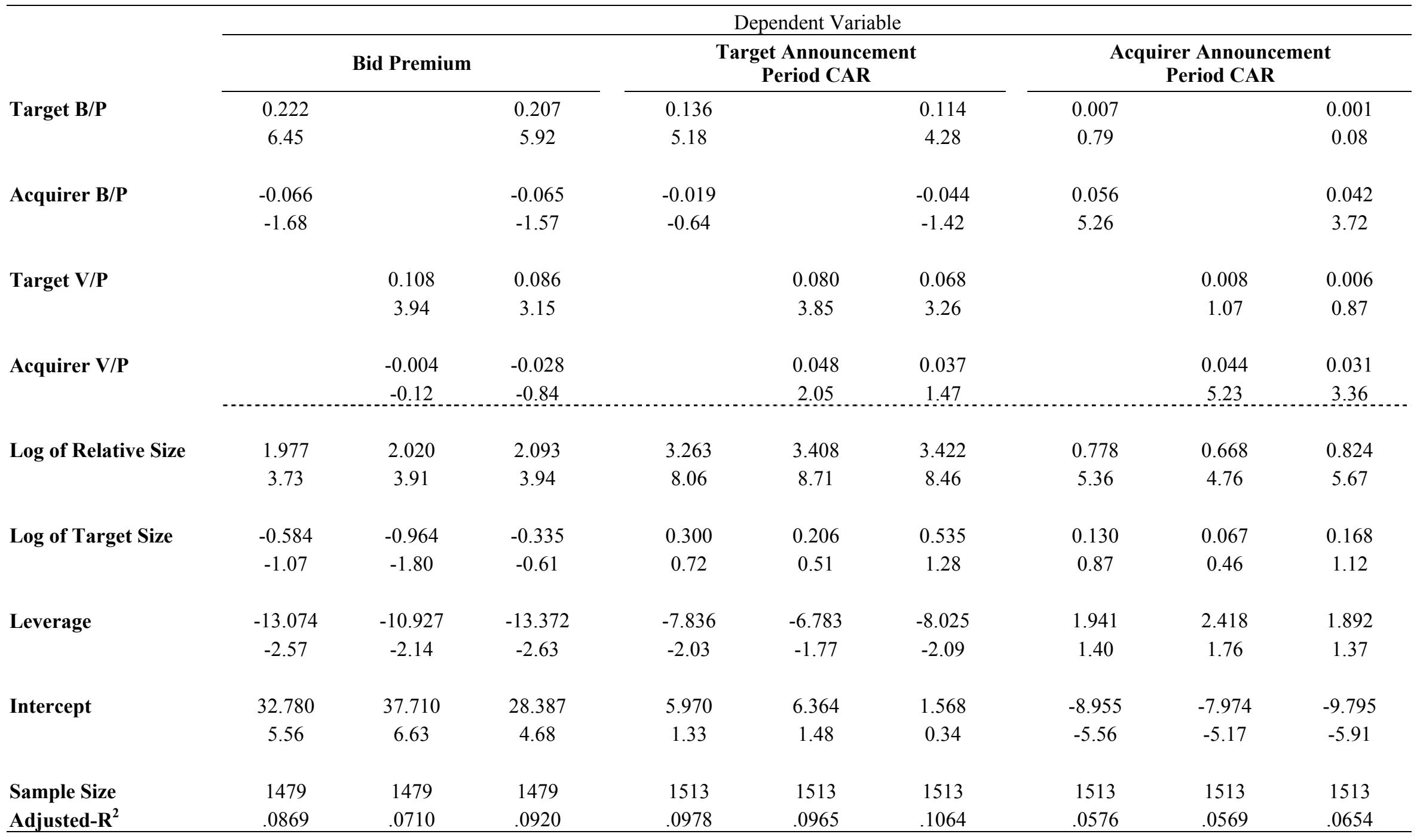




\section{Appendix Table}

\section{Summary of Predictions and Main Findings}

This table summarizes the predictions from the Misvaluation Hypothesis and main results of the paper. Panel A reports the acquirer minus target mean differences in book-to-price ratios and in residual income value-to-price ratios for given means of payment and form of transaction, and also reports cash minus stock mean differences in valuation ratios among acquirers, and among targets. The relation between takeover characteristics and target and acquirer misvaluation measures in univariate tests is reported in Panel B and in multivariate tests is reported in Panel C. The intrinsic value $\mathrm{V}$ is calculated from the Residual Income Model. Cash $=1$ if the acquisition is all cash; 0 otherwise. Stock $=1$ if the acquisition is all stock; 0 otherwise. Tender Offer $=1$ if the acquisition is a tender offer; 0 otherwise. Hostile $=1$ if the acquisition is viewed as hostile by target management; 0 otherwise. Success $=1$ if the offer is successful; 0 otherwise. Acquirer and target announcement period cumulative abnormal returns (CAR) are measured over the three days (-1,1) around the announcement (day 0) of the acquisition. Bid premium is the ratio of the bid price offered by the acquirer to the target stock price 5 days prior to the announcement of the takeover bid. Pred is for predictions and Res is for results.

\begin{tabular}{|c|c|c|c|c|c|c|c|c|c|c|c|c|c|c|}
\hline \multicolumn{15}{|c|}{ Panel A: Valuation Difference } \\
\hline & \multicolumn{10}{|c|}{ Acquirer - Target } & \multicolumn{4}{|c|}{ Cash - Stock } \\
\hline & \multicolumn{2}{|c|}{ All } & \multicolumn{2}{|c|}{ Cash } & \multicolumn{2}{|c|}{ Stock } & \multicolumn{2}{|c|}{ Tender Offer } & \multicolumn{2}{|c|}{ Merger } & \multicolumn{2}{|c|}{ Target } & \multicolumn{2}{|c|}{ Acquirer } \\
\hline & Pred & Res & Pred & Res & Pred & Res & Pred & Res & Pred & Res & Pred & Res & Pred & Res \\
\hline $\mathbf{B} / \mathbf{P}$ & - & -*** & - & $-* * *$ & - & $-* * *$ & - & _*** & - & - $* * *$ & + & $+* * *$ & + & $+* * *$ \\
\hline $\mathbf{V} / \mathbf{P}$ & - & $-* * *$ & - & - ** & - & - *** & - & & - & -*** & + & $+* * *$ & + & $+* * *$ \\
\hline
\end{tabular}

\section{Panel B: Univariate Tests}

\begin{tabular}{|c|c|c|c|c|c|c|c|c|c|c|c|c|c|c|c|c|}
\hline & \multicolumn{2}{|c|}{ Cash } & \multicolumn{2}{|c|}{ Stock } & \multicolumn{2}{|c|}{ Tender Offer } & \multicolumn{2}{|c|}{ Hostile } & \multicolumn{2}{|c|}{ Success } & \multicolumn{2}{|c|}{ Bid Premium } & \multicolumn{2}{|c|}{ Target CAR } & \multicolumn{2}{|c|}{ Acquirer CAR } \\
\hline & Pred & Res & Pred & Res & Pred & Res & Pred & Res & Pred & Res & Pred & Res & Pred & Res & Pred & Res \\
\hline Target B/P & + & $+* * *$ & - & $-* * *$ & + & $+* * *$ & + & $+* * *$ & - & _*** & + & $+* * *$ & + & $+* * *$ & + & $+* * *$ \\
\hline Acquirer B/P & + & $+* * *$ & - & $-* * *$ & & $+* * *$ & & & & & - & $-* * *$ & - & $-*$ & + & $+* * *$ \\
\hline Target V/P & + & $+*$ & - & $-* * *$ & + & $+* *$ & + & $+* * *$ & - & $-*$ & + & & + & & + & $+* * *$ \\
\hline
\end{tabular}


Appendix Table contd.

Summary of Predictions and Main Findings

\section{Panel C: Multivariate Tests}

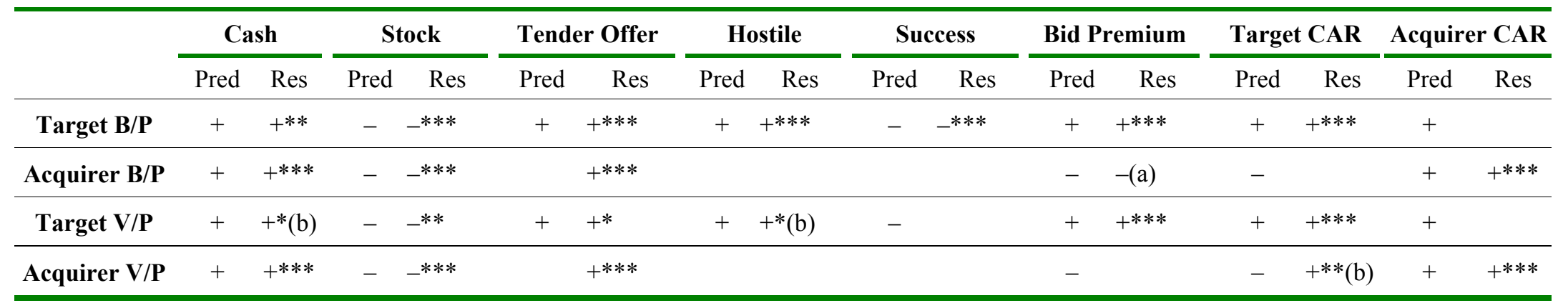

\section{NOTES}

1. $+(-)$ indicates a positive (negative) relation between the $\mathrm{B} / \mathrm{P}$ and $\mathrm{V} / \mathrm{P}$ measures with the takeover characteristics.

2. $* * *, * * *$ indicate significance at the $1 \%, 5 \%$ and $10 \%$ levels, two-tailed tests respectively.

3. The significance levels for the univariate tests are based on overall sample, and those for the multivariate tests are for the regressions using all four misvaluation measures.

4. (a) indicates significance at $12 \%$ level, two-tailed test.

5. (b) reports significance for the regression when acquirer and target $\mathrm{V} / \mathrm{P}$ measures are included but acquirer and target $\mathrm{B} / \mathrm{P}$ measures are excluded. For these cells, the variable was insignificant when all four misvaluation ratios are included in the regression. 